\title{
Onset of Electrical Excitability during a Period of Circus Plasma Membrane Movements in Differentiating Xenopus Neurons
}

\author{
Eric C. E. Olson \\ Department of Biology, University of California at San Diego, La Jolla, California 92093
}

\begin{abstract}
Living neurons are usually first identifiable in primary cultures at the time of neurite initiation, and studies of excitability have been restricted largely to the subsequent period. A morphological early marker is described that identifies neurons for wholecell voltage-clamp recordings before neurite initiation. Video time-lapse recordings of cultured cells dissociated from neurectoderm of Xenopus neural plate stage embryos reveal cells demonstrating circus movements, in which blebs of plasma membrane propagate around the cell circumference within a period of several minutes. All neurons demonstrate circus movements before morphological differentiation; the fraction of cells exhibiting circus movements that differentiate morphologically depends on the substrate on which they are cultured. Blockade of circus activity with cytochalasin B does
\end{abstract}

not prevent neuronal differentiation. Circus movements are not neurectoderm-specific because they similarly predict differentiation of myocytes developing in mesodermal cultures.

Initially inexcitable, neurons develop voltage-dependent $\mathrm{K}^{+}$, $\mathrm{Na}^{+}$, and $\mathrm{Ca}^{2+}$ currents during the period of several hours in which they exhibit circus movements. The early development of depolarization-induced elevations of $\left[\mathrm{Ca}^{2+}\right]_{i}$ several hours before morphological differentiation corresponds to the previously described onset of functionally significant spontaneous elevations of $\left[\mathrm{Ca}^{2+}\right]_{i}$ in these neurons and demonstrates a role for early expression of voltage-dependent ion channels.

Key words: Xenopus spinal neurons; circus movements; lobopodia; early neuronal marker; sodium currents; calcium currents; potassium currents
Embryonic forms of excitability play key roles in neuronal migration and differentiation. In the period between final mitosis and morphological differentiation, neurons in both the cortex (Rakic, 1972; McConnell, 1991) and the spinal cord (Chu-Wang et al., 1981; Leber and Sanes, 1995) migrate radially to achieve their appropriate positions. Significantly, these movements can be influenced by $\mathrm{Ca}^{2+}$ influx (Komuro and Rakic, 1992, 1993, 1995); however, biophysical recordings from neurons in this developmental period are lacking, in part because of the scarcity of in vitro models in which postmitotic but morphologically undifferentiated neurons can be distinguished from other cell types found in primary cultures of embryonic neural tissue.

Xenopus spinal neurons cultured from neurula stage embryos exhibit spontaneous, transient elevations of intracellular calcium $\left(\left[\mathrm{Ca}^{2+}\right]_{\mathrm{i}}\right)$ before and after neurite initiation that are required for appropriate expression of the neurotransmitter GABA and maturation of $\mathrm{K}^{+}$current kinetics (Holliday and Spitzer, 1990; Desarmenien and Spitzer, 1991; Spitzer et al., 1993; Gu and Spitzer, 1995). By the earliest time of neurite initiation, primary spinal neurons display $\mathrm{Ca}^{2+}$-dependent action potentials and mature $\mathrm{Ca}^{2+}$ current density (Spitzer and Lamborghini, 1976; Barish, 1986; O’Dowd et al., 1988; Spitzer, 1991), implying that voltage-

\footnotetext{
Received April 5, 1996; revised June 3, 1996; accepted June 3, 1996.

E.C.E.O. was supported by a National Science Foundation predoctoral fellowship and by National Institutes of Health Grant T32 GM08107. This work was supported by National Institutes of Health Grant NS15918 to N.C.S. I thank Nicholas C. Spitzer for his expert advice and financial support for this project as well as his assistance in the preparation of this manuscript. I thank Chris Hempel and Drs. Evanna Gleason, Jeff Rohrbough, and Michael Ferrari for their helpful comments on this manuscript; members of the Spitzer laboratory for critique of the experiments; and Steve Watt and I-Teh Hsieh for invaluable technical assistance. Special thanks to Susan Light for constant encouragement.

Correspondence should be addressed to Eric C. E. Olson, Department of Biology, 0357, University of California at San Diego, 9500 Gilman Drive, La Jolla, CA 92093-0357.

Copyright (C) 1996 Society for Neuroscience $0270-6474 / 96 / 165117-13 \$ 05.00 / 0$
}

dependent currents appear at an earlier stage. Characterization of voltage-dependent currents in these neurons before morphological differentiation, however, is limited to a study of $\mathrm{Na}^{+}$currents in round cells that were presumed to be neurons by their adherence to myocytes (Kidokoro and Sand, 1989).

Video time-lapse recordings of cells cultured from neurula stage Xenopus embryos now reveal distinctive changes in morphology that predict subsequent differentiation of both primary neurons and myocytes. All neurons in cultures of dissociated neurectoderm are derived from a subset of cells that display circus movements in which a single bleb repeatedly propagates around the circumference of the cell with a period of 1-2 min. Similarly, in cultures of paraxial mesoderm, all myocytes are derived from cells that display circus movements. Circus movements were originally identified in cultures of cells dissociated from amphibian gastrulae (Roux, 1894; Holtfreter, 1946a,b; Karasaki, 1957; Sirakami, 1963) as well as in motile cells such as amoebae (Rhumbler, 1898) and invertebrate amoebocytes (Loeb, 1928). Subsequent studies in amphibia implicated circus movements in the morphogenetic rearrangements of gastrulation (Johnson and Adelman, 1981, 1984), but circus movements were not related to cell fate.

Using circus movements as an early marker for subsequent differentiation enabled answers to specific questions about neurons in the period before their display of stereotypical morphology. Do voltage-dependent inward and outward currents develop in spinal neurons before morphological differentiation? Does the appearance of inward $\mathrm{Ca}^{2+}$ currents coincide with the appearance of spontaneous elevations of $\left[\mathrm{Ca}^{2+}\right]_{i}$ in these cultures? Does blockade of circus movements prevent subsequent neuronal differentiation? This work provides insight into early differentiation of neurons and myocytes and should permit further analysis of their development. 
Preliminary accounts of some of these findings have been published previously (Olson and Gu, 1993; Olson, 1994).

\section{MATERIALS AND METHODS}

Culture procedures. Enriched cultures from each embryonic primordium (ectoderm, mesoderm, and endoderm) were prepared from neural plate stage Xenopus laevis embryos (stage 15; Nieuwkoop and Faber, 1967), using modifications of established dissection protocols (Kidokoro et al., 1980; Holliday et al., 1991; Gu and Spitzer, 1993). Neurectoderm, paraxial mesoderm, notochord, and archenteron roof cultures were made by dissection of the posterior half of the neural plate. Separation of embryonic neurectoderm from paraxial mesoderm, notochord, and endoderm was achieved by further dissection for $5-10 \mathrm{~min}$ in collagenase B- (1 $\mathrm{mg} / \mathrm{ml}$ ) (Boehringer Mannheim, Indianapolis, IN) low $\mathrm{Ca}^{2+}$ medium containing (in $\mathrm{mm}$ ): $116.6 \mathrm{NaCl}, 0.67 \mathrm{KCl}, 0.5 \mathrm{CaCl}_{2}$, and 8 HEPES, $\mathrm{pH}$ adjusted to 7.8 with $\mathrm{NaOH}$. For ventral ectoderm cultures, the ventral region of the embryo opposite the neural plate was excised, and the underlying lateral plate mesoderm and endoderm were removed by subsequent dissection in collagenase $\mathrm{B}-$ low $\mathrm{Ca}^{2+}$ medium (as above). Each tissue was then dissociated separately in divalent-free solution containing (in mM): $116.6 \mathrm{NaCl}, 0.67 \mathrm{KCl}, 0.4$ EDTA, and 4.6 Tris, pH adjusted to 7.8 with $\mathrm{HCl}$, and plated on $35 \mathrm{~mm}$ diameter tissue culture dishes (Costar, Cambridge, MA) treated with laminin/polylysine $(1 \mathrm{ml}$ of $0.25 \mathrm{mg} / \mathrm{ml}$ polylysine followed by $1 \mathrm{ml}$ of $10 \mu \mathrm{g} / \mathrm{ml}$ laminin) (Sigma, St. Louis). The laminin/polylysine substrate was chosen, in contrast to the tissue culture plastic used previously (O'Dowd et al., 1988), because the number of morphologically differentiated neurons was enhanced (see Results). Cells were cultured in saline containing (in $\mathrm{mm}$ ): $116.6 \mathrm{NaCl}$, $0.67 \mathrm{KCl}, 1.31 \mathrm{MgSO}_{4}, 2 \mathrm{CaCl}_{2}$, and 4.6 Tris, $\mathrm{pH}$ adjusted to 7.8 with $\mathrm{HCl}$, at low density (e.g., $\sim 300$ cells $/ \mathrm{cm}^{2}$ in neurectoderm cultures). Dissociated cells were plated at a time when there are no morphologically identifiable neurons in vivo. The earliest differentiating neurons can be recognized by neurite initiation $\sim 6 \mathrm{hr}$ after plating in neurectoderm cultures (Spitzer and Lamborghini, 1976), and differentiating myocytes can be recognized as early as $2 \mathrm{hr}$ after plating by their flattened and elongated shapes. Myocytes were rarely observed except in paraxial mesoderm cultures. If more than five myocytes were found in cultures other than paraxial mesoderm cultures, those cultures were considered contaminated and were discarded. Five myocytes in a single neurectoderm culture would represent a contamination level of $\sim 1.0 \%$; this dissection protocol thus produces relatively pure cultures. In some experiments, neural plates were split by drawing all the cells from a single dissociated neural plate up into a glass pipette and then streaking streams of cells first onto one dish and then onto another until all cells were plated.

Neurepithelium and sensorial layer cultures. Fragments of neurepithelia were removed by briefly placing dejellied embryos in divalent-free solution and teasing away the most superficial layer of the neurectoderm with a tungsten dissection needle or jeweler's forceps. The deep (sensorial) layer of the neurectoderm was obtained by excising the same neural plate, regionally lacking neurepithelium, and dissecting and removing mesoderm and endoderm in collagenase B- low $\mathrm{Ca}^{2+}$ medium. Neurepithelial and sensorial tissues then were dissociated separately in divalent-free solution and plated as above.

Differentiation of circus cells: time-lapse video microscopy. Circus cells were distinguished by their motile plasma membranes. Transmitted light images in neurectoderm cultures were collected with a Bio-Rad MRC600 argon confocal system fitted with a fiber optic transmission detector (Bio-Rad, Hercules, CA) on a Zeiss microscope with an Olympus $20 \times / 0.4$ NA water immersion objective; cells were superfused continuously with culture saline at $\sim 0.25 \mathrm{ml} / \mathrm{min}$ for the duration of these recordings. Images were collected at $10 \mathrm{sec}$ intervals for the first $4 \mathrm{hr}$ of recording and subsequently at 20 or 30 min intervals for up to $8 \mathrm{hr}$, during which morphological differentiation was scored. Individual cells were illuminated for $<0.2 \mathrm{sec}$ during collection of each image. Additional time-lapse recordings were collected without perfusion using phase-contrast optics (Leitz $10 \times / 0.25$ NA objective) on a Leitz inverted microscope fitted to a Cohu High Performance CCD camera (Cohu, San Diego, CA). Cells were subjected to constant low level illumination, and images were acquired continuously. In both protocols, images were recorded to timelapse VCR at 72- to 360-hr speeds (GYRR, Anaheim, CA) for subsequent analysis. An average of 40 cells were scored in each time-lapse recording.

Differentiation of circus cells: two-time-point assay. To examine a larger population of cells without continuous video time-lapse recording, a two-time-point circus assay was used. Cultured cells were examined under phase-contrast optics (Zeiss $16 \times / 0.35 \mathrm{NA}$ objective) with a Zeiss inverted microscope shortly after plating. Because circus activity is continuous, cells demonstrating circus movements were distinguished by their phasebright plasma membranes. To assay differentiation, fields of interest were marked on the bottom of dishes, and the number of cells within a marked field exhibiting circus movements at $1.5-4.0 \mathrm{hr}$ in culture was compared with the number of differentiated myocytes or neurons within the same field at $16-24 \mathrm{hr}$ in culture. Given the time-lapse results that none of the round (noncircus) cells examined at 1.5-4.0 hr contributed to the differentiated cells at 16-24 hr, all differentiated cells were attributed to the circus population at $1.5-4.0 \mathrm{hr}$. An average of 170 cells per marked field were scored in this assay.

Pharmacology of circus activity. Responses of circus cells to cytochalasin B or colcemid (both from Sigma) were examined in neurectoderm cultures. Marked fields of cells were examined for the numbers of cells positive for circus movements before and $1 \mathrm{hr}$ after application of drug and were compared to control plates treated with equal volumes of drug vector alone (0.05-0.1\% DMSO; Sigma). The number of cells showing circus movements at $1 \mathrm{hr}$ was converted to percentage inhibited by dividing by the number of active circus cells at the beginning of the hour.

Voltage-clamp recordings of neurectoderm circus cells. Using minor modifications of procedures described previously (O'Dowd et al., 1988; Desarmenien and Spitzer, 1991), conventional whole-cell voltage-clamp recordings (Hamill et al., 1981) were made of outward current $\left(I_{\mathrm{Kv}}\right)$ and inward currents $\left(I_{\mathrm{Na}}\right.$ and $\left.I_{\mathrm{Ca}}\right)$ in developing circus cells cultured from neurectoderm. Recording pipettes were pulled from $100 \mu \mathrm{l}$ microcaps (Drummond Scientific, Broomall, PA); typical pipette resistance was 2-3 $\mathrm{M} \Omega$ in extracellular recording solution. Most successful recordings were obtained when seals were made on blebs. Recordings with series resistance in excess of $8 \mathrm{M} \Omega$ or input resistance $<400 \mathrm{M} \Omega$ were discarded. Data were acquired with an Axopatch-1D amplifier with a CV-4 headstage (1 G $\Omega$; Axon Instruments, Foster City, CA) and stored and analyzed using PCLAMP software (Axon Instruments) on a DTK (PC compatible) computer. Leak subtraction was scaled from the currents induced by hyperpolarizing steps one eighth the amplitude of the depolarizing test potentials and subtracted in PCLAMP software.

Outward currents were always recorded in solutions that blocked $I_{\mathrm{Ca}}$ and usually in the presence of $1 \mu \mathrm{g} / \mathrm{ml}$ tetrodotoxin (TTX) to block $I_{\mathrm{Na}}$. TTX was omitted in some recordings to allow simultaneous detection of $I_{\mathrm{Na}}$ in the same cells. The extracellular recording solution contained (in $\mathrm{mM}): 80 \mathrm{NaCl}, 3 \mathrm{KCl}, 5 \mathrm{MgCl}_{2}, 10 \mathrm{CoCl}_{2}$, and 5 HEPES, pH 7.4 (Desarmenien et al., 1993). The pipette solution contained (in mM): 100 $\mathrm{KCl}$ and 5 HEPES; $\mathrm{pH}$ was adjusted to 7.4 by adding an estimated 3.5-5.0 mM KOH (Ribera and Spitzer, 1987). Cells were stepped from a holding potential of $-80 \mathrm{mV}$ to $+30 \mathrm{mV}$ for $30 \mathrm{msec}$. Measurements of $I_{\mathrm{Kv}}$ were obtained by averaging outward current $27-28.5 \mathrm{msec}$ after the onset of the voltage step to avoid contamination by rapidly inactivating $I_{\mathrm{Na}}$.

Inward currents were recorded in solutions that blocked only the potassium currents expressed in these neurons $\left(I_{\mathrm{Kv}}, I_{\mathrm{KA}}\right.$, and $\left.I_{\mathrm{Kc}}\right)$ (O'Dowd et al., 1988), so that both $I_{\mathrm{Na}}$ and $I_{\mathrm{Ca}}$ could be recorded simultaneously in the same cells. The extracellular recording solution contained (in mM): $80 \mathrm{NaCl}, 40$ TEA-Cl, $3 \mathrm{KCl}, 2 \mathrm{CaCl}_{2}$, and 5 HEPES; $\mathrm{pH}$ was adjusted to 7.4 with $\mathrm{NaOH}$. The pipette solution contained (in $\mathrm{mM}$ ): $95 \mathrm{CsCl}, 10$ EGTA, and 10 HEPES; $\mathrm{MgCl}_{2}$-ATP and cAMP (2 mM each) were added immediately before recording, and $\mathrm{pH}$ was adjusted to 7.4 with $\mathrm{CsOH}$. Cells were stepped from a holding potential of $-100 \mathrm{mV}$ to $0 \mathrm{mV}$ for $30 \mathrm{msec} . I_{\mathrm{Na}}$ was determined by measuring the peak inward current within $5 \mathrm{msec}$ of the onset of depolarization, whereas $I_{\mathrm{Ca}}$ was measured by averaging the inward current $27-28 \mathrm{msec}$ after depolarization to $0 \mathrm{mV}$. Cell capacitance was determined either from single exponential fits of the decay of the capacitive transient obtained with the 10 $\mathrm{mV}$ voltage step, or in most cases was measured by capacitance compensation at the amplifier. Capacitance was converted to membrane surface area, assuming $1 \mu \mathrm{F} / \mathrm{cm}^{2}$ (O'Dowd et al., 1988).

Calcium imaging. Cultures were incubated for 30-40 min with the fluorescent $\mathrm{Ca}^{2+}$ indicator Fluo-3AM (Molecular Probes, Eugene, OR) to load cells (Minta et al., 1989). Fluo-3AM was solubilized in DMSO to a concentration of $50 \mu \mathrm{g} / 10 \mu \mathrm{l}$ and added to culture saline to achieve a final concentration of $2 \mu \mathrm{M}$. At the end of the loading period, excess dye was washed out with three rinses of culture medium over a $10 \mathrm{~min}$ period. Images were collected at 5 or $10 \mathrm{sec}$ intervals with a Bio-Rad MRC600 argon laser confocal microscope fitted with the BHS (fluorescein) filter block and recorded to videotape. $\mathrm{KCl}$, caffeine (both substituted for $\mathrm{NaCl}$ 


\section{A}
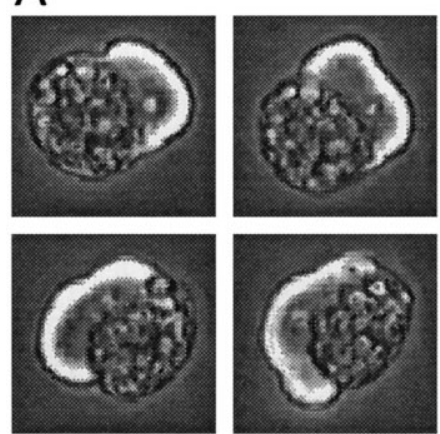

B
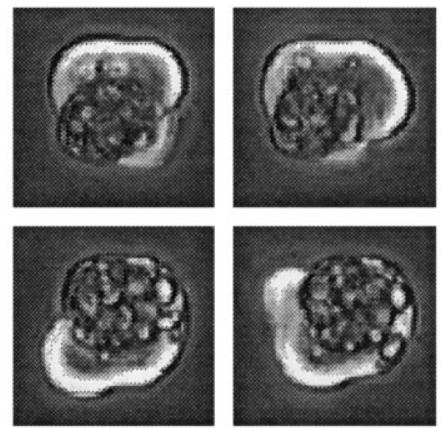

C
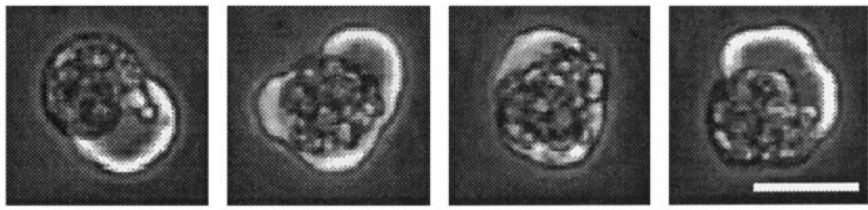

Figure 1. Circus movements and blebbing in a single neurectoderm cell at $2 \mathrm{hr}$ in culture. A, Counterclockwise circus movements; phase-contrast images at $10 \mathrm{sec}$ intervals. The cell demonstrated continuous counterclockwise behavior for $18 \mathrm{~min}$. $B$, Clockwise circus movements, images at $10 \mathrm{sec}$ intervals $\sim 17 \mathrm{~min}$ after images in $A$. $C$, Left to right, Images at $2 \mathrm{~min}$ intervals of random blebbing. Scale bar, $25 \mu \mathrm{m}$.

in culture saline), and acetylcholine were bath-applied by superfusion to stimulate cells. Recordings were analyzed on-line or by replay of tapes with video import to a Macintosh IIci computer with a QuickCapture video frame-grabber board (Data Translation, Marlboro, MA). Mean fluorescent pixel intensities of regions of interest within cells in each image were calculated using a custom macro within the IMAGE 1.47 program (W. Rasband, National Institutes of Health).

Statistics. Values are presented as mean \pm SEM and are considered significantly different by any of several tests if $p<0.05$. Analysis was performed with StatView Student software (Abacus Concepts, Berkeley, CA).

\section{RESULTS}

\section{Circus movements in neurectoderm cultures}

Two morphologically distinguishable classes of cells were observed in primary cultures of Xenopus neurectoderm during the initial few hours after plating and before the time period of neurite initiation. The most striking were cells demonstrating circus movements (Holtfreter, 1946a), characterized by circumferentially rotating blebs (also called lobopodia; Fujinami and Kageyama, 1975), which were readily visualized by phase-contrast microscopy (Fig. 1A,B). Although individual cells occasionally demonstrated other types of blebbing in addition to circus movements (Fig. 1C), all cells with phase-bright, motile blebs (5-20 $\mu \mathrm{m}$ protrusions of membrane) are termed circus cells, because circus movements were the predominant form of blebbing in these cultures. The remaining cells did not demonstrate circus movements and are referred to as round cells.

In a given circus cell, lobopodia traveled either counterclockwise (Fig. $1 A$ ) or clockwise (Fig. $1 B$ ), and typically circumnavigated with a period of 1-2 min. The speed of lobopodial circumnavigation seen in dissociated neurectoderm cells corresponds to the speed reported previously for gastrula stage cells engaged in circus movements $(0.6-1.2 \mu \mathrm{m} / \mathrm{sec}$ ) (Fujinami and Kageyama, 1975). Cells demonstrated uninterrupted circus movements for hours, and in some cells the direction of movement (clockwise or counterclockwise) persisted for $>20$ revolutions. Circus movements were not dependent on substrate adhesion, because cells plated on a nonadhesive substrate (Sigma-Cote-treated tissue culture plastic) demonstrated circus movements, as did cells in suspension. It is therefore likely that circus movements occurred in all three dimensions but that only planar movements were readily apparent. Circus movements were also capable of generating force, because lobopodia were capable of displacing loosely adherent neighboring cells, as observed previously (Johnson, 1976).

\section{Only neurectoderm and paraxial mesoderm cells exhibit persistent circus activity}

To determine whether circus movements are specific to cells derived from prospective neural tissue, cultures from other embryonic tissues were examined. Percentages of circus cells in cultures made from neurectoderm, paraxial mesoderm, notochord, archenteron roof, and ventral ectoderm tissues were determined at two time points after plating; the first was between 0 and $30 \mathrm{~min}$, and the second was after $90 \mathrm{~min}$ (usually between 90 and $180 \mathrm{~min}$ ).

Cultures made from different tissues of the neurula stage embryo (stage 15) had characteristic percentages of circus cells 30 min after plating (transient activity) (Fig. 2A, dark bars). Thus circus movements were not specific to cultured neural tissue. Cultures from dorsal tissues such as neurectoderm, notochord, and paraxial mesoderm that are known to be actively lengthening along the anterior/posterior axis (Keller, 1975, 1976; Keller et al., 1992) had significantly higher percentages of circus cells than ventral ectoderm (Fig. 2A, asterisks). This is consistent with previous observations of the early gastrula embryo (stage 10), which show that cultures from tissues undergoing morphogenesis, such as the blastopore lip, have higher percentages of circus cells 30 min after plating than cultures from other regions, such as the prospective endoderm (Johnson, 1976).

Cells that ceased circus movements between 30 and $90 \mathrm{~min}$ usually appeared round and indistinguishable from other round cells in culture. In some instances, former circus cells appeared flattened or spread on the substrate. These spread cells were distinguished by the occasional presence of short $(<10 \mu \mathrm{m})$ and phase-dark processes. No spread cells were observed in any culture at $30 \mathrm{~min}$, but spread cells were observed in archenteron roof and paraxial mesoderm cultures at $90 \mathrm{~min}$.

Cultures derived from neurectoderm and paraxial mesoderm demonstrated substantial numbers of circus cells 90 min after culturing (persistent activity) (Fig. 2A, open bars). Persistent circus movements continued uninterrupted for hours and were occasionally observed in 1-d-old cultures. The gradual decline in the percentage of persistent circus cells (Fig. $2 B$, diamonds) in the neurectoderm was paralleled by the appearance of morphologi- 
Figure 2. Tissue specificity of circus movements examined in enriched cultures from each germ layer of the neural plate (inset) as well as the ventral ecto$\operatorname{derm} . A$, Circus cells are found in cultures of neurectoderm, ventral ectoderm, mesoderm, and endoderm of neural plate stage embryos immediately after dissociation and plating, but only neuron-enriched (neurectoderm) and myocyte-enriched (paraxial mesoderm) cultures contain appreciable numbers of circus cells after 90 min in culture (persistent activity). Asterisks indicate $30 \mathrm{~min}$ means that are significantly different from the 30 min mean of ventral ectoderm, a tissue thought to undergo relatively little extension (95\% significance level, one-factor ANOVA). Circus cells were recognized by phase-bright membranes observed with phase-contrast microscopy. $n>300$ cells in at least three separate cultures for paraxial mesoderm, notochord, and endoderm, and $n>1300$ cells in at least seven cultures for neurectoderm and ventral ectoderm. $B$, Decline in percentage of circus cells in neurectoderm cultures and appearance of neurons in the same cultures. Repeated observations of three marked fields reveals that the percentage of circus cells decreases rapidly during the first $90 \mathrm{~min}$ after plating (diamonds). The percentage of morphologically recognizable neurons (circles) increases steadily from $4-13 \mathrm{hr}$ in culture; at $25 \mathrm{hr}$, neurons comprise $\sim 7 \%$ of all cells. $n=939$ cells from three cultures. In some cases, values were obtained by averaging data linearly extrapolated between observation points.
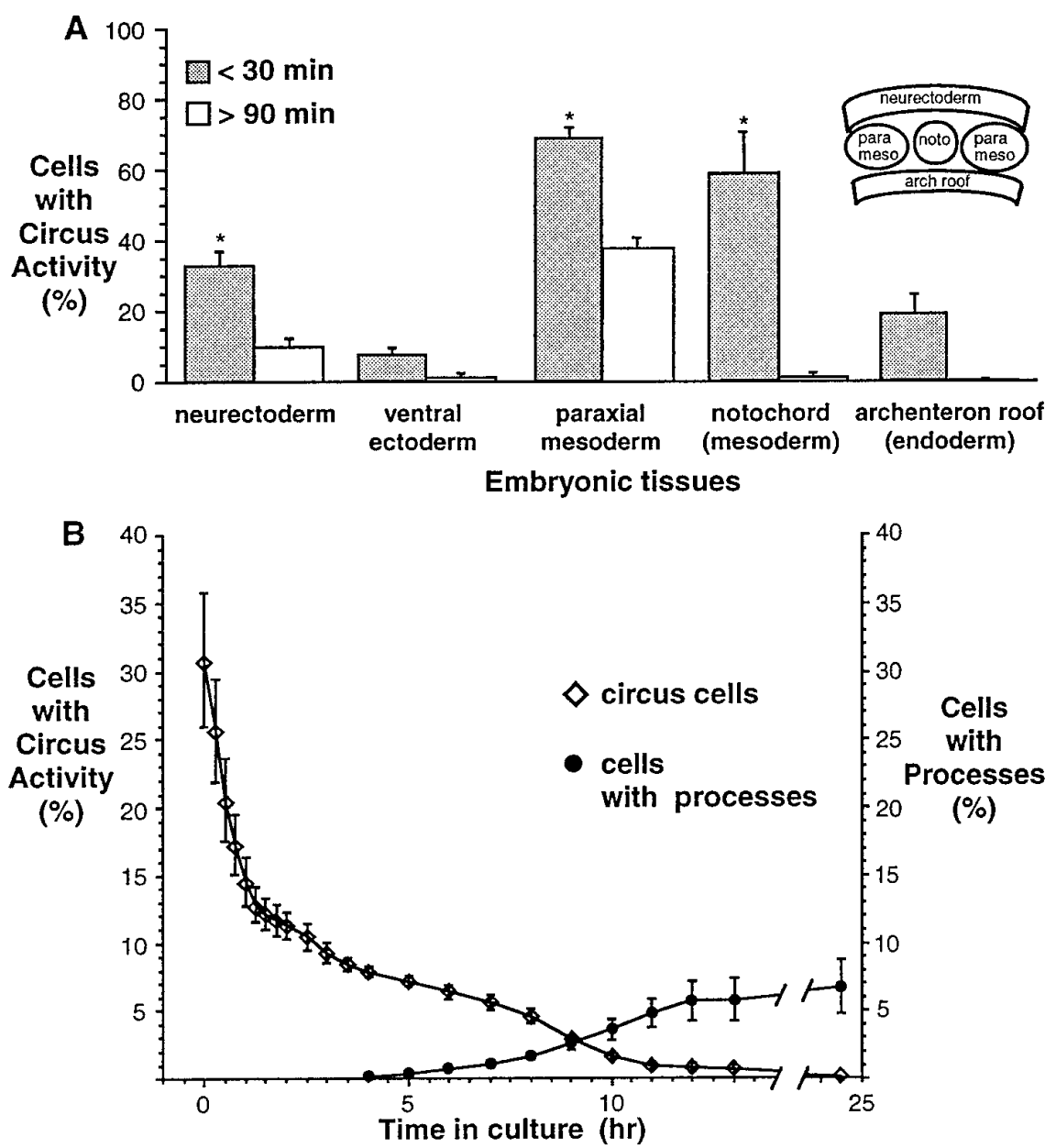

cally differentiated cells (Fig. 2B, circles). This observation raised the possibility that persistent circus movements are a characteristic feature of early differentiation of neurons.

\section{Circus movements are a marker for neuronal differentiation}

To determine the relationship between persistent circus movements and subsequent neuronal differentiation, video time-lapse recordings of 10 microscopic fields in neurectoderm cultures containing circus and round cells were made throughout the period of morphological differentiation. In these recordings, all neurons demonstrated continuous circus movements before morphological differentiation (Fig. $3 A$ ). No neurons were derived from the $85 \%$ of total cells that lacked circus movements $(n=342$ round cells) in the same recordings. Of the 60 circus cells examined, 25 differentiated into neurons with processes terminating in growth cones (Fig. 3C, explicit neurons). An additional 14 differentiated into spread cells that lacked processes longer than one cell diameter but had a large nuclear region, unobstructed by yolk platelets, characteristic of neurons in these cultures (Fig. $3 C$, implicit neurons). Time-lapse recordings also revealed five circus cells that underwent cytokinesis (Fig. 3C, divide), and 16 that ceased circus activity and became round cells (Fig. $3 C$, round). In separate experiments in which cells were identified by morphology at $16-24 \mathrm{hr}$ in culture, most explicit $(91 \%, n=53)$ and implicit neurons $(68 \%, n=60)$ responded to depolarization with $50 \mathrm{mM}$ $\mathrm{KCl}$ by elevating intracellular $\mathrm{Ca}^{2+}$, assessed with Fluo-3AM, suggesting the presence of voltage-dependent $\mathrm{Ca}^{2+}$ channels. No round cells responded in this manner $(n=32)$.

Do both layers of the neurectoderm produce cultures with circus cells? The midneurula stage neurectoderm is bilayered, with the deep or sensorial layer composed of cells that give rise to most primary and some secondary neurons, and the more superficial layer composed of pigmented epithelial cells that give rise to most secondary or later differentiating neurons (Hartenstein, 1989). Cultures from the deep, sensorial layer contained circus cells and produced neurons. In contrast, circus cells were not present in large numbers $(<2 \%$ of total cells at $60 \mathrm{~min})$ in cultures from the superficial layer of neural ectoderm, and these cultures did not produce neurons. These results are consistent with the observation that most primary neurons are derived from the deep layer. Cultures from pigmented epithelium from regions outside the neural plate also exhibited $<2 \%$ circus cells at 30 min postplating, indicating that the epithelium is a tissue that does not generate circus cells.

\section{Substrate dependence of neuronal differentiation}

The fraction of circus cells that differentiated morphologically as explicit neurons depended on the substrate to which cells attached. Consistent with time-lapse recordings of neuronal differentiation on laminin/polylysine treated dishes, time-lapse recordings of neurectoderm cultures plated on untreated dishes indicated that all neurons were derived from the circus cell population $(n=34)$ and that round cells did not differentiate $(n=$ 

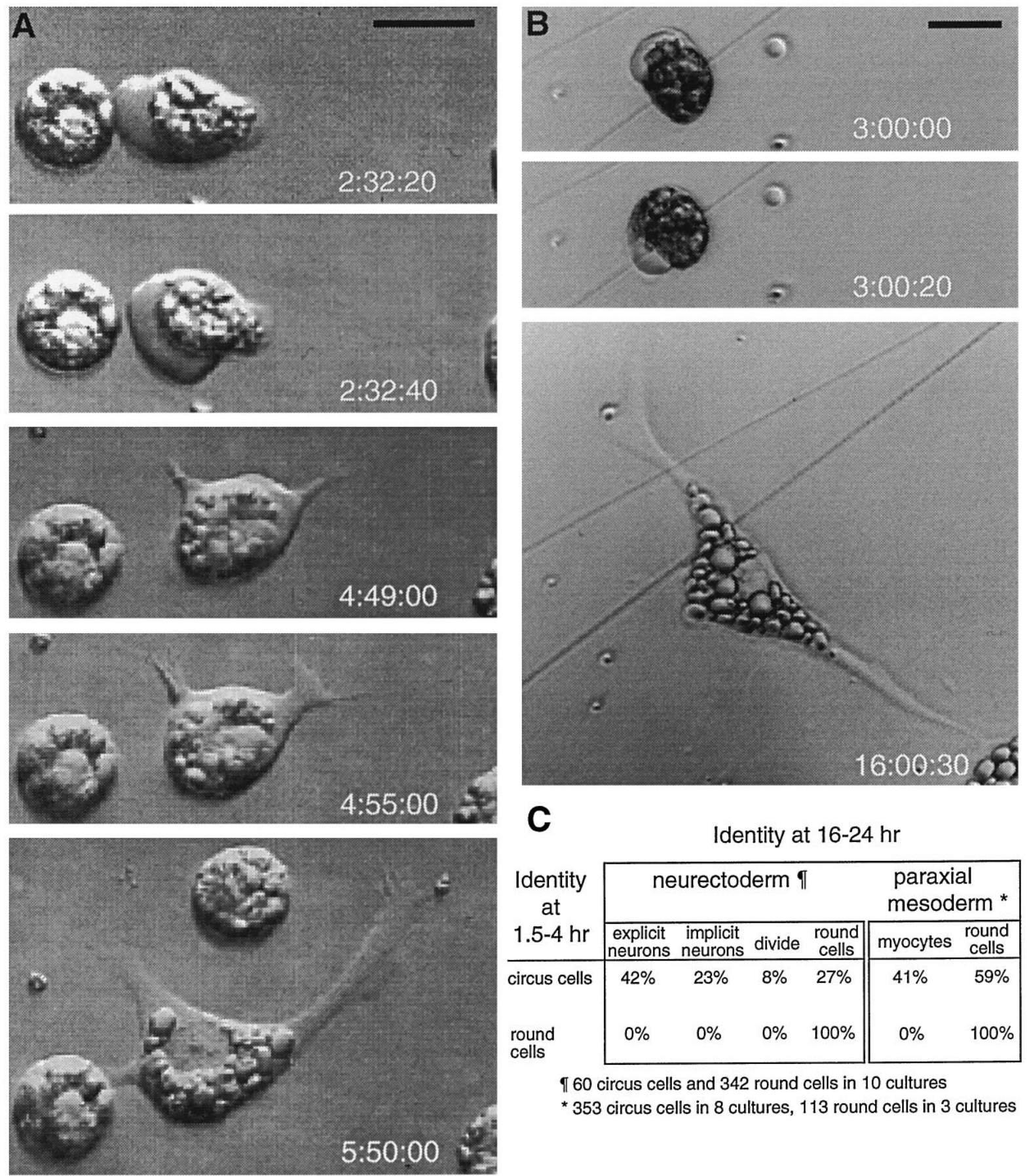

Identity at $16-24 \mathrm{hr}$

\begin{tabular}{|c|c|c|c|c|c|c|}
\hline \multirow{2}{*}{$\begin{array}{l}\text { Identity } \\
\text { at } \\
1.5-4 \mathrm{hr}\end{array}$} & \multicolumn{4}{|c|}{ 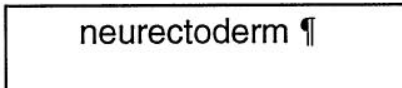 } & \multicolumn{2}{|c|}{$\begin{array}{l}\text { paraxial } \\
\text { mesoderm * }\end{array}$} \\
\hline & \begin{tabular}{|c|} 
explicit \\
neurons
\end{tabular} & $\begin{array}{c}\text { implicit } \\
\text { neurons }\end{array}$ & divide & $\begin{array}{l}\text { round } \\
\text { cells } \\
\end{array}$ & myocytes & $\begin{array}{l}\begin{array}{l}\text { round } \\
\text { cells }\end{array} \\
\end{array}$ \\
\hline circus cells & $42 \%$ & $23 \%$ & $8 \%$ & $27 \%$ & $41 \%$ & $59 \%$ \\
\hline $\begin{array}{l}\text { round } \\
\text { cells }\end{array}$ & $0 \%$ & $0 \%$ & $0 \%$ & $100 \%$ & $0 \%$ & $100 \%$ \\
\hline
\end{tabular}

I 60 circus cells and 342 round cells in 10 cultures

* 353 circus cells in 8 cultures, 113 round cells in 3 cultures

Figure 3. Morphologically differentiated neurons and myocytes are derived from persistent circus cells in culture. $A$, Circus cell from the neurectoderm that differentiates morphologically as a neuron. The neurectoderm cell at left lacks membrane excursions and fails to differentiate morphologically. $B$, Circus cell from the paraxial mesoderm that differentiates as a myocyte. Times (after culturing) of image acquisition are noted at lower right of each frame. Scale bars, $25 \mu \mathrm{m}$. $C$, Differentiated fates of persistent circus cells from neurectoderm and paraxial mesoderm cultures are indicated as the percentage of the initial circus and round cell populations. Video time-lapse microscopy of 10 neurectoderm cultures reveals that neuronal differentiation is the predominant fate of persistent circus cells. A two-time-point protocol applied to 11 paraxial mesoderm cultures, examining a larger population of cells, revealed that circus cells became myocytes in paraxial mesoderm cultures and that round cells failed to differentiate.

113). Cultures made from single neural plates were then split between laminin/polylysine-coated and untreated tissue culture plastic dishes and scored for the number of circus cells at $90 \mathrm{~min}$ and the number of neurons at 16-24 hr. Although equal percentages of circus cells were present on each substrate $(p>0.12$, two-tailed $t$ test; $n=14$ paired cultures), circus cells plated on laminin/polylysine were twofold more likely to differentiate than circus cells from the same dissociated neural plate attached to tissue-culture plastic ( $64 \pm 6 \%$ vs $28 \pm 3 \%$; for 14 paired cultures, average of 20 circus cells/field). Moreover, neurites were $2.1 \pm 0.4$ times longer in laminin cultures versus tissue culture plastic $(n=$ 9 paired cultures, $\sim 25$ neurites per culture). Accordingly, total 


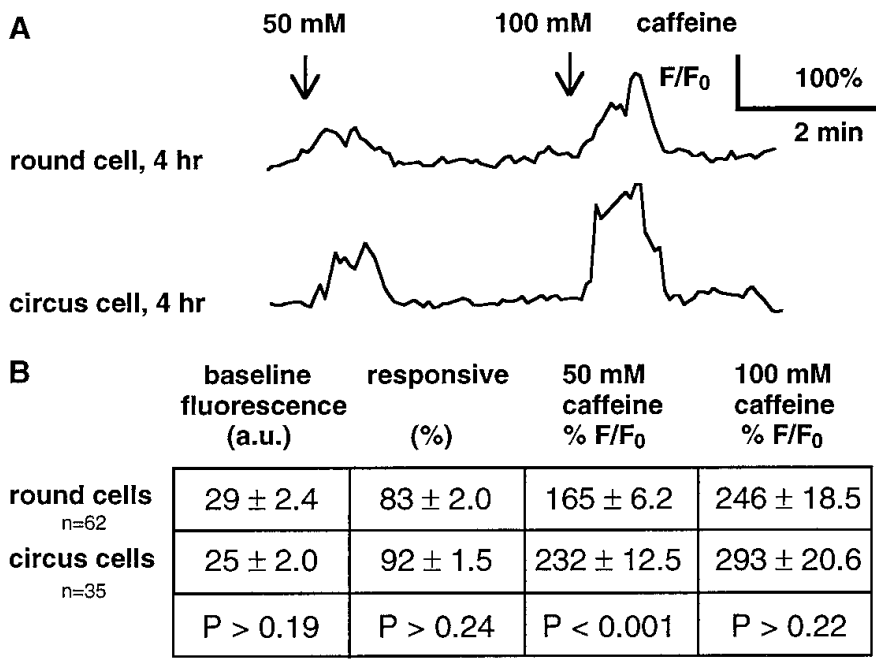

Figure 4. Both round and circus neurectoderm cells demonstrate vitality with responses to caffeine. Cells were loaded with Fluo-3AM, a fluorescent $\mathrm{Ca}^{2+}$ indicator, and superfused with medium containing caffeine for $60 \mathrm{sec}$ at the indicated times. Elevations of fluorescence indicate elevations of $\left[\mathrm{Ca}^{2+}\right]_{\mathrm{i}} . A$, Cells respond to caffeine at $4 \mathrm{hr}$ in culture, demonstrating the presence of loaded $\mathrm{Ca}^{2+}$ stores and active intracellular buffering mechanisms. $B$, There is no significant difference between round and circus cells in baseline fluorescence (arbitrary units) and percentage of cells responsive to $50 \mathrm{~mm}$ caffeine. Amplitudes of responses to $50 \mathrm{~mm}$ caffeine are significantly different but are not different at $100 \mathrm{~mm}$ caffeine (Mann-Whitney $U$ tests for all comparisons). Values are from four cultures at $4-6 \mathrm{hr}$.

cell counts showed that approximately twofold more neurons were observed to have differentiated on laminin than on tissue culture plastic ( $280 \pm 12$ vs $117 \pm 23$ cells; $n \geq 3$ cultures). The disparity between the percentage of circus cells that differentiated in this two-time-point protocol and the percentage observed in the timelapse analysis are significant $(64 \%$ and $42 \%$, respectively; $p<$ 0.05 , unpaired $t$ test) and may be attributable to inhibition of differentiation by the illumination necessary for time-lapse imaging or to underestimation of the number of circus cells in the two-time-point analysis. These results agree with previous reports that laminin encourages differentiation of Xenopus neurons (Grant and Tseng, 1989) and indicate that both the quantity of circus cells at $90 \mathrm{~min}$ and their exclusive contribution to the differentiated neuronal population at $16-24 \mathrm{hr}$ is not particular to the laminin/polylysine substrate.

The failure of round cells to differentiate into neurons in neurectoderm cultures does not seem to be attributable to their lack of vitality. $\mathrm{Ca}^{2+}$ imaging revealed that both round and circus cells loaded and retained Fluo-3AM, a $\mathrm{Ca}^{2+}$ indicator that requires an intact plasma membrane for loading and functional intracellular esterases for retention. Baseline fluorescence levels were not significantly different between round and circus cells examined at 4-6 hr in neurectoderm cultures, indicating that both classes of cells maintained a low $\left[\mathrm{Ca}^{2+}\right]_{\mathrm{i}}$ against a large $\left[\mathrm{Ca}^{2+}\right]_{\mathrm{e}}$ (Fig. $4 B$ ). Superfusion of caffeine, which stimulates $\mathrm{Ca}^{2+}$ release from stores, generated transient elevations of $\left[\mathrm{Ca}^{2+}\right]_{i}$ in both round and circus cells in neurectoderm cultures, indicating the presence of $\mathrm{Ca}^{2+}$ stores (Fig. 4A,B). Because round and circus cells were not distinguishable by the criteria of dye loading, fluorescent baseline, and responsiveness to caffeine, both classes of cells survived the dissociation and plating procedure.

\section{Circus activity also a marker for differentiation of myocytes}

To determine whether persistent circus movements precede differentiation of non-neuronal cell types, myocyte differentiation was examined in paraxial mesoderm cultures. Paraxial mesoderm cultures, also called myocyte-enriched cultures, have been used previously in studies of differentiation of embryonic Xenopus myocytes (Linsdell and Moody, 1994, 1995; Ernsberger and Spitzer, 1995). Although fate-mapping indicates that paraxial mesoderm produces other cell types in addition to muscle, myocytes were the predominant morphologically differentiated class of cell in these cultures, as assayed by elongate shapes and responses to $\mathrm{KCl}$ and acetylcholine. Most elongate cells at 19-21 hr in paraxial mesoderm cultures responded to $100 \mu \mathrm{M}$ acetylcholine and $50 \mathrm{~mm}$ $\mathrm{KCl}$ by elevating $\left[\mathrm{Ca}^{2+}\right]_{\mathrm{i}}$, assessed by increases in Fluo-3 fluorescence $(88 \%, n=41$ cells). Therefore, morphology at 16-24 hr was used as an indicator of myocyte differentiation.

Because myocytes failed to assume clear bipolar morphology or to demonstrate acetylcholine responses after being subjected to the illumination necessary for time-lapse imaging, a modification of the two-time-point protocol was used to ascertain whether persistent circus movements predict myocyte differentiation. Fields containing circus cells at $90 \mathrm{~min}$ in paraxial mesoderm cultures and companion fields without circus cells were compared for the number of myocytes they contained at 16-24 hr in culture. Only fields that contained circus cells at $90 \mathrm{~min}$ in culture later contained myocytes (Fig. 3C), and fields lacking circus cells at 90 min did not contain myocytes subsequently. The probability that a field that lacked circus cells could give rise to a differentiated myocyte under these culture conditions was statistically remote ( $p<0.05$, Mann-Whitney $U ; n=3$ paired fields), indicating that myocytes are derived from the circus cell population. Using the two-time-point protocol, $41 \%$ of paraxial mesoderm circus cells examined at $90 \mathrm{~min}$ differentiated into myocytes by 16-24 hr (Fig. $3 C$ ). These results suggest that circus movements are a precursor of cellular spreading and the subsequent morphological and functional differentiation of cultured embryonic Xenopus myocytes.

\section{Mechanism of generation of circus activity}

To better understand the generation of circus activity, and to determine whether circus movements are necessary for cellular spreading and subsequent morphological differentiation, cytochalasin B and colcemid were tested for their ability to inhibit circus activity and prevent neuronal differentiation in neurectoderm cultures. To assay inhibition, microscopic fields containing neurectoderm circus cells were examined before and $1 \mathrm{hr}$ after application of either agent. Cytochalasin B, which interferes with actin polymerization, inhibited circus movements in a rapid and reversible manner $(n=8)$. Circus movements ceased within 2.5 min of application of $5 \mu \mathrm{M}$ cytochalasin B. This effect was slowly reversed after washout (Fig. 5A) $(n=5)$. Colcemid, which interferes with microtubule polymerization, did not inhibit circus activity at concentrations up to $25 \mu \mathrm{M}$ (Fig. 5A). These results suggest that actin but not tubulin polymerization is required for circus activity and are in agreement with previous findings that cytochalasin B stops circus activity in dissociated cells from Medaka gastrulae (Fujinami, 1976).

Prevention of circus activity with cytochalasin B does not completely arrest subsequent neuronal morphological differentiation. Neurectoderm cultures chronically treated with up to $10 \mu \mathrm{M}$ cytochalasin B, starting $1.5 \mathrm{hr}$ after plating and $\sim 4.5 \mathrm{hr}$ before neurite outgrowth, contained morphologically differentiated neu- 

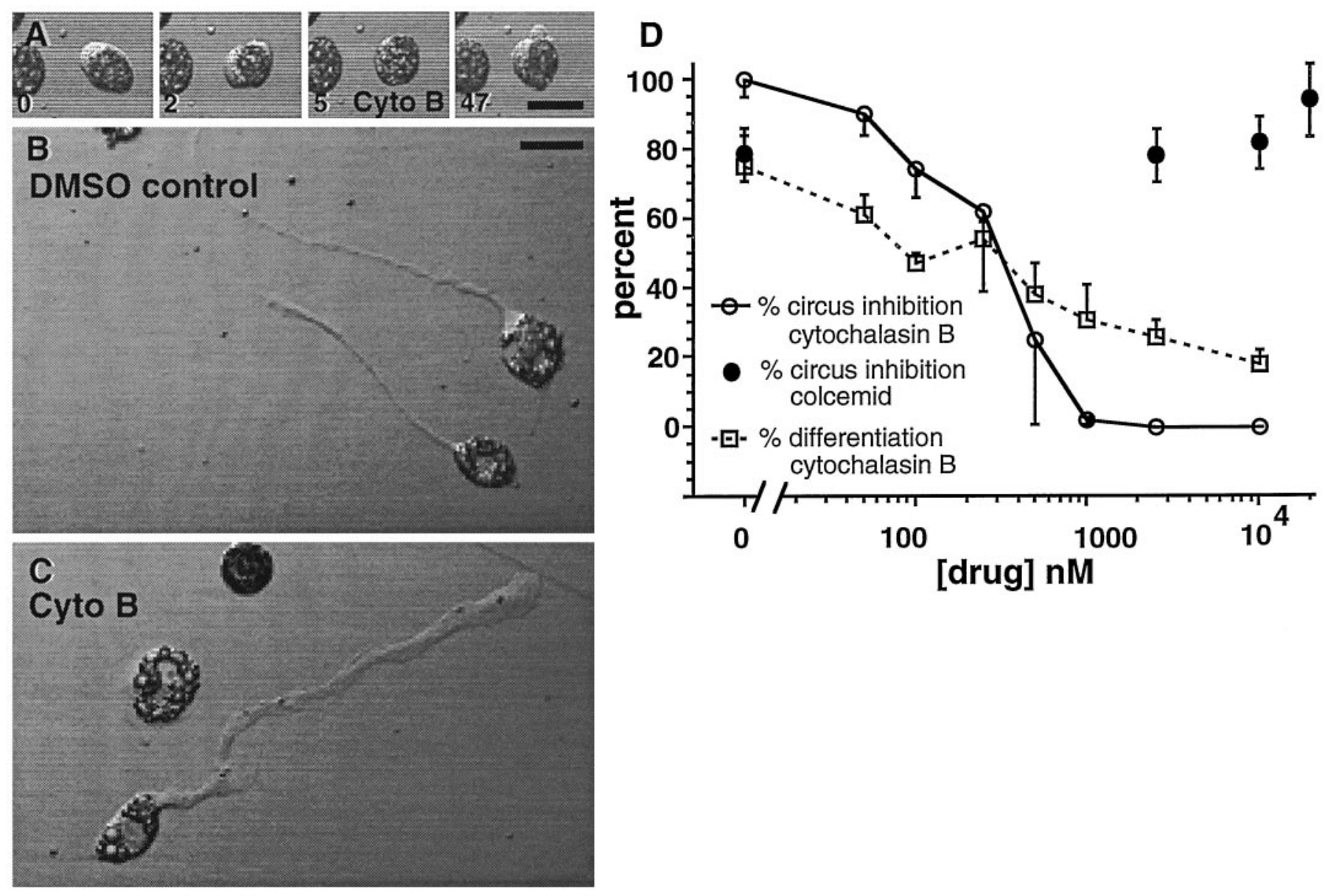

Figure 5. Cytochalasin B abolishes circus movements but does not prevent neuronal differentiation. $A$, Circus movements are rapidly and reversibly blocked by $5 \mu \mathrm{M}$ cytochalasin B, implicating an actin microfilament-dependent process. Transmission images of a neurectoderm circus cell at 5 hr in culture acquired at times (in minutes) noted at bottom left of each frame. Application and washout were at 2.5 min and 14 min, respectively. B, Normal morphology of neurons cultured in medium containing $0.05 \%$ DMSO. $C$, Neuronal morphology of cells cultured in medium containing $2.5 \mu \mathrm{M}$ cytochalasin B; application from 1.5-18.0 hr in culture. Processes are broader and growth cones lack filopodia. D, Dose-response relations for the inhibition of circus activity and neuronal differentiation by cytochalasin B and colcemid. The percentage of circus cells that differentiate into neurons was assayed with the two-time-point assay. Cytochalasin B stopped circus movements at concentrations $>1.0 \mu \mathrm{M}$ (open circles), whereas colcemid had no effect at concentrations as high as $25 \mu \mathrm{M}$ (filled circles). Chronic blockade of circus activity by higher concentrations of cytochalasin B reduces the number of cells that acquire a neuronal morphology, but does not completely prevent neuronal differentiation (squares). Chronic application of colcemid produced gross abnormalities in neuronal morphology, making neuronal differentiation difficult to score (data not shown).

rons the following day (Fig. 5C,D, open squares). Differentiated neurons typically had broader processes and more spatulate growth cones than controls (Fig. $5 B, C$ ), indicating that cytochalasin $B$ alters but does not prevent the outgrowth of neurites. Neurons chronically treated with cytochalasin B also demonstrated elevations of $\left[\mathrm{Ca}^{2+}\right]_{\mathrm{i}}$ after $50 \mathrm{~mm} \mathrm{KCl}$ superfusion, assessed as increases in Fluo-3 fluorescence, suggesting the presence of voltage-dependent $\mathrm{Ca}^{2+}$ channels (data not shown). The percentage of circus cells that differentiate was inhibited with increasing concentrations of cytochalasin $\mathrm{B}$ (Fig. 5D). These results raise the possibility that circus movements are necessary for the subsequent differentiation of some neurons; however, concentrations of cytochalasin B sufficient to abolish circus activity do not fully abolish neuronal differentiation, indicating that for other neurons circus movements are not necessary for subsequent differentiation. Although the curves for circus inhibition and neuronal inhibition have similar $50 \%$ inhibition points at $\sim 300 \mathrm{~nm}$ cytochalasin $\mathrm{B}$, circus inhibition is sigmoidal, whereas neural inhibition is linear (Fig. 5D). Thus, cytochalasin B may influence two different processes more, and circus inhibition and inhibition of neuronal differentiation may be mechanistically distinct. Medium taken from cultures treated for $24 \mathrm{hr}$ with $10 \mu \mathrm{M}$ cytochalasin B rapidly stopped circus activity on application at $2.5 \mu \mathrm{M}$ to fresh neurectoderm cultures, confirming that this agent was active throughout the prolonged treatment period. These results demonstrate that persistent circus activity is not a general prerequisite for the expression of neuronal morphology, although chronic cytochalasin B treatment can cause qualitative and quantitative differences in neuronal differentiation.

\section{Circus cells from neurectoderm develop voltage- dependent outward $\mathrm{K}^{+}$currents}

Previous work demonstrated that all morphologically differentiated Xenopus spinal neurons examined at 6-9 $\mathrm{hr}$ in culture have voltage-dependent $\mathrm{K}^{+}, \mathrm{Na}^{+}$, and $\mathrm{Ca}^{2+}$ currents $\left(I_{\mathrm{Kv}}, I_{\mathrm{Na}}, I_{\mathrm{Ca}}\right)$ (O'Dowd, 1988); they also exhibit a $\mathrm{Ca}^{2+}$-dependent $\mathrm{Cl}^{-}$current $\left(I_{\mathrm{Cl}(\mathrm{Ca})}\right)$ but lack strictly voltage-dependent $I_{\mathrm{Cl}}$ (Hussy, 1991); however, the developmental time course of the appearance of these currents before morphological differentiation was unknown. Therefore, whole-cell voltage-clamp recordings were made from 

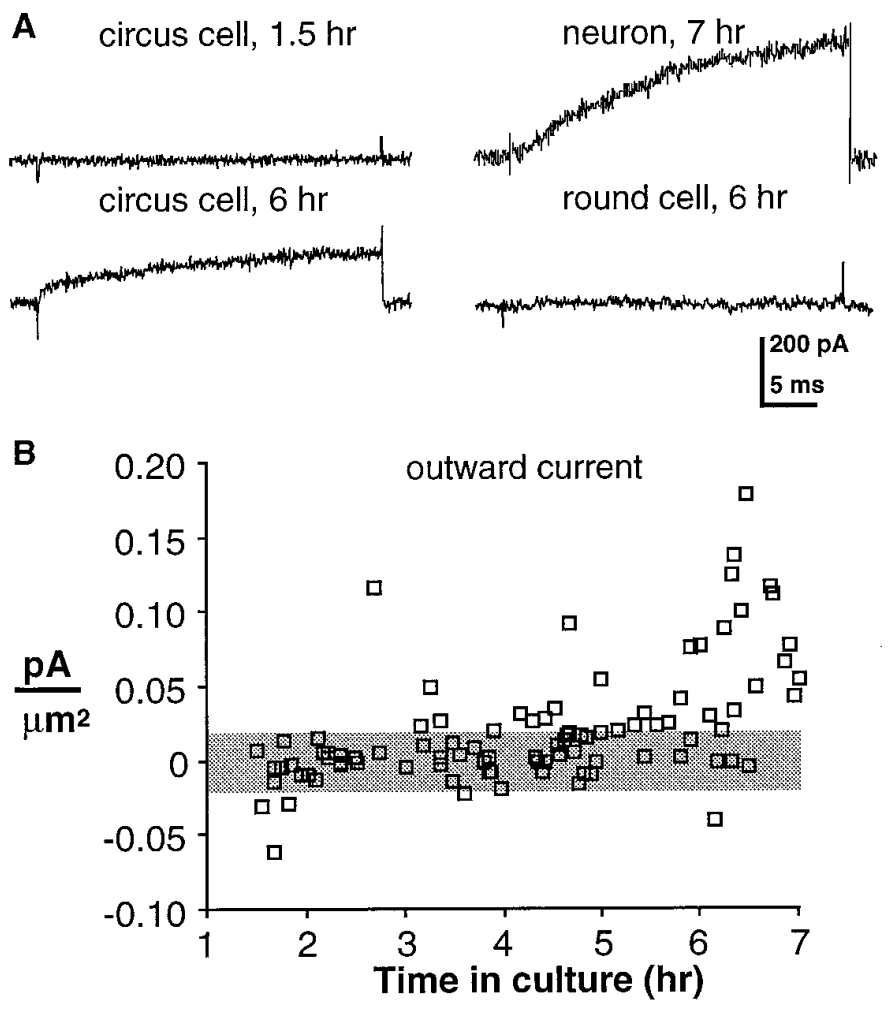

Figure 6. Appearance of voltage-dependent outward current in circus cells from neurectoderm. Voltage-clamp recordings during the first $6 \mathrm{hr}$ after plating are shown; currents were elicited by a $30 \mathrm{msec}$ voltage step from a holding potential of $-80 \mathrm{mV}$ to $+30 \mathrm{mV}$. $A$, Voltage-dependent outward current is not recorded from a neurectoderm circus cell $1.5 \mathrm{hr}$ after plating, but is present in a circus cell at $6 \mathrm{hr}$ in vitro (left top and bottom). A neuron demonstrates outward current at $6 \mathrm{hr}$ in culture (right top). A round cell does not demonstrate outward currents (right bottom). $B$, Aggregate measurements of outward current during early development. Current densities $\left(\mathrm{pA} / \mu \mathrm{m}^{2}\right)$ of individual circus cells are plotted against time in culture. Mean peak-to-peak recording noise is denoted by the shaded horizontal bar.

circus cells in neurectoderm cultures during the first $6 \mathrm{hr}$ after plating. $I_{\mathrm{Kv}}$ was recorded as in previous studies (O'Dowd et al., 1988; Desarmenien and Spitzer, 1991) and was observed in an increasing percentage of neurectoderm circus cells during the first $6 \mathrm{hr}$ in culture (corresponding to stages 15 through 23 in vivo). The current was similar to that seen in morphologically differentiated neurons at $6 \mathrm{hr}$ (Fig. 6A) (O'Dowd et al., 1988). Circus cells lacked $I_{\mathrm{Kv}}$ at $1.5 \mathrm{hr}$ in culture $(n=10)$; it was first detected above noise (typically \pm 20 $\mathrm{pA}$ or $\left.\pm 0.02 \mathrm{pA} / \mu \mathrm{m}^{2}\right)$ in a single cell at $2 \mathrm{hr}$ in vitro. Most circus cells $(74 \%, n=19)$ sampled at $6 \mathrm{hr}$ in culture demonstrated $I_{\mathrm{Kv}}(0.085 \pm$ $0.013 \mathrm{pA} / \mu \mathrm{m}^{2} ; n=14$ ) (Fig. $6 B$ ). Its amplitude in these cells was $\sim 60 \%$ of that observed for age-matched neurons $(0.136 \pm 0.045$ $\left.\mathrm{pA} / \mu \mathrm{m}^{2} ; n=5\right)$. Although two of eight round cells demonstrated outward currents marginally above noise $\left(0.027\right.$ and $\left.0.028 \mathrm{pA} / \mu \mathrm{m}^{2}\right)$, the mean current density in round cells was less than the noise level $\left(0.009 \pm 0.005 \mathrm{pA} / \mu \mathrm{m}^{2} ; n=8\right)$.

\section{Circus cells from neurectoderm develop voltage- dependent inward $\mathrm{Na}^{+}$and $\mathrm{Ca}^{2+}$ currents}

$I_{\mathrm{Na}}$ and $I_{\mathrm{Ca}}$ also appear in neurons during their period of circus movements. Circus cells examined at $6 \mathrm{hr}$ in culture had both rapidly inactivating and sustained components of inward current, only a rapidly inactivating component, or neither (Fig. 7A, left). The rapidly inactivating current was blocked by $1 \mu \mathrm{g} / \mathrm{ml}$ TTX, and the remaining sustained current was blocked by $2 \mathrm{~mm} \mathrm{Ni}^{2+}$ (Fig. $7 B$, left), suggesting that the principal inward currents in circus cells are carried by $\mathrm{Na}^{+}$and $\mathrm{Ca}^{2+}$, as they are in young Xenopus spinal neurons (Fig. 7B, right) (O'Dowd et al., 1988). Accordingly, in analysis of their development, the rapidly inactivating peak of inward currents was attributed to the voltage-dependent $\mathrm{Na}^{+}$ current $\left(I_{\mathrm{Na}}\right)$, and the sustained component measured near the end of the voltage step was attributed to voltage-dependent $\mathrm{Ca}^{2+}$ current $\left(I_{\mathrm{Ca}}\right)$. This protocol allowed direct comparison of $I_{\mathrm{Na}}$ and $I_{\mathrm{Ca}}$ in single cells. The sustained component was measured $\sim 12$ time constants from the peak of the rapidly inactivating component; thus there was negligible contamination of the sustained current by the rapidly inactivating current. Reciprocal contamination of the rapid component by the sustained component was small, because $I_{\mathrm{Na}}$ is approximately fourfold larger than $I_{\mathrm{Ca}}$ at early time periods and has a time to peak of $<1.5 \mathrm{msec}$, at which time $I_{\mathrm{Ca}}$ has achieved only $20 \%$ of its amplitude (Fig. $7 B$, left).

Circus cells developed $I_{\mathrm{Na}}$ and $I_{\mathrm{Ca}}$ during the first $6 \mathrm{hr}$ in culture. At $1.5 \mathrm{hr}$ in vitro, no inward currents were recorded, and $I_{\mathrm{Na}}$ and $I_{\mathrm{Ca}}$ were first detected above noise at $2 \mathrm{hr}$. By $6 \mathrm{hr}$ in culture, $I_{\mathrm{Na}}$ was detected in $58 \%$ of circus cells $(n=26)$ and had a mean density of $-0.296 \pm 0.084 \mathrm{pA} / \mu \mathrm{m}^{2}(n=15)($ Fig. $7 A, C)$. $I_{\mathrm{Ca}}$ was detected in $38 \%$ of circus cells; in these cells the mean density of $I_{\mathrm{Ca}}$ was $-0.047 \pm 0.007 \mathrm{pA} / \mu \mathrm{m}^{2}(n=10)($ Fig. $7 A, D)$. All cells with detectable $I_{\mathrm{Ca}}$ also demonstrated $I_{\mathrm{Na}}$, and $20 \%$ of circus cells at $6 \mathrm{hr}$ had only $I_{\mathrm{Na}}$. Neurons at 5-7 hr in culture exhibited a mean density of $I_{\mathrm{Na}}$, about twice that of age-matched circus cells $\left(-0.579 \pm 0.051 \mathrm{pA} / \mu \mathrm{m}^{2}\right)$, whereas $I_{\mathrm{Ca}}$ was similar to that in circus cells $\left(-0.052 \pm 0.008 \mathrm{pA} / \mu \mathrm{m}^{2} ; n=5\right)$. All neurons had detectable $I_{\mathrm{Na}}$ and $I_{\mathrm{Ca}}$. Although one of six round cells demonstrated $I_{\mathrm{Ca}}$ marginally above noise $\left(-0.026 \mathrm{pA} / \mu \mathrm{m}^{2}\right)$, the mean current densities of both $I_{\mathrm{Na}}$ and $I_{\mathrm{Ca}}$ in round cells were within the noise ( $n=6 ; 6-8 \mathrm{hr}$ in culture). Circus cells did not appear to increase in size during this period, because the mean surface area at $1.5 \mathrm{hr}\left(1060 \pm 40 \mu \mathrm{m}^{2} ; n=10\right)$ was not different from that at $6 \mathrm{hr}\left(1070 \pm 70 \mu \mathrm{m}^{2} ; p>0.89 ; n=18\right)$. In contrast, neurons at $6 \mathrm{hr}$ in culture had a mean surface area of $1340 \pm 120$ $\mu \mathrm{m}^{2}(n=5)$, and thus were $25 \%$ larger $(p<0.03)$ than agematched circus cells.

\section{Calcium elevations in response to depolarization with KCl}

Previous work demonstrated that $\mathrm{Ca}^{2+}$ influx through voltagedependent $\mathrm{Ca}^{2+}$ channels regulates aspects of spinal neuron differentiation (Desarmenien and Spitzer, 1991; Spitzer et al., 1993; $\mathrm{Gu}$ and Spitzer, 1995). Because voltage-clamped $\mathrm{Ca}^{2+}$ currents in circus cells were typically small, $\mathrm{Ca}^{2+}$ imaging was used to determine whether they are sufficient to produce detectable elevations of $\left[\mathrm{Ca}^{2+}\right]_{i}$ in response to depolarization and to confirm the developmental profile of expression of $\mathrm{Ca}^{2+}$ currents during the first $6 \mathrm{hr}$ in culture.

Cultured cells were loaded with Fluo-3AM and superfused with $50 \mathrm{~mm} \mathrm{KCl}$. Responses were defined as elevations $\geq 150 \%$ of baseline that occurred within $30 \mathrm{sec}$ of $\mathrm{KCl}$ superfusion. All neurons and a subpopulation of circus cells exhibited elevation of $\left[\mathrm{Ca}^{2+}\right]_{\mathrm{i}}$ when depolarized, suggesting the expression of voltagedependent $\mathrm{Ca}^{2+}$ channels in these cells. When cells were responsive, the initial application of $50 \mathrm{~mm} \mathrm{KCl}$ produced an elevation of fluorescence 1.5- to 4-fold over baseline. This response was blocked by application of $2 \mathrm{~mm} \mathrm{Ni}^{2+}$ or $10 \mathrm{~mm} \mathrm{Co}^{2+}$ (Fig. $8 A, B$ ), which block voltage-dependent $\mathrm{Ca}^{2+}$ channels in neurons after 

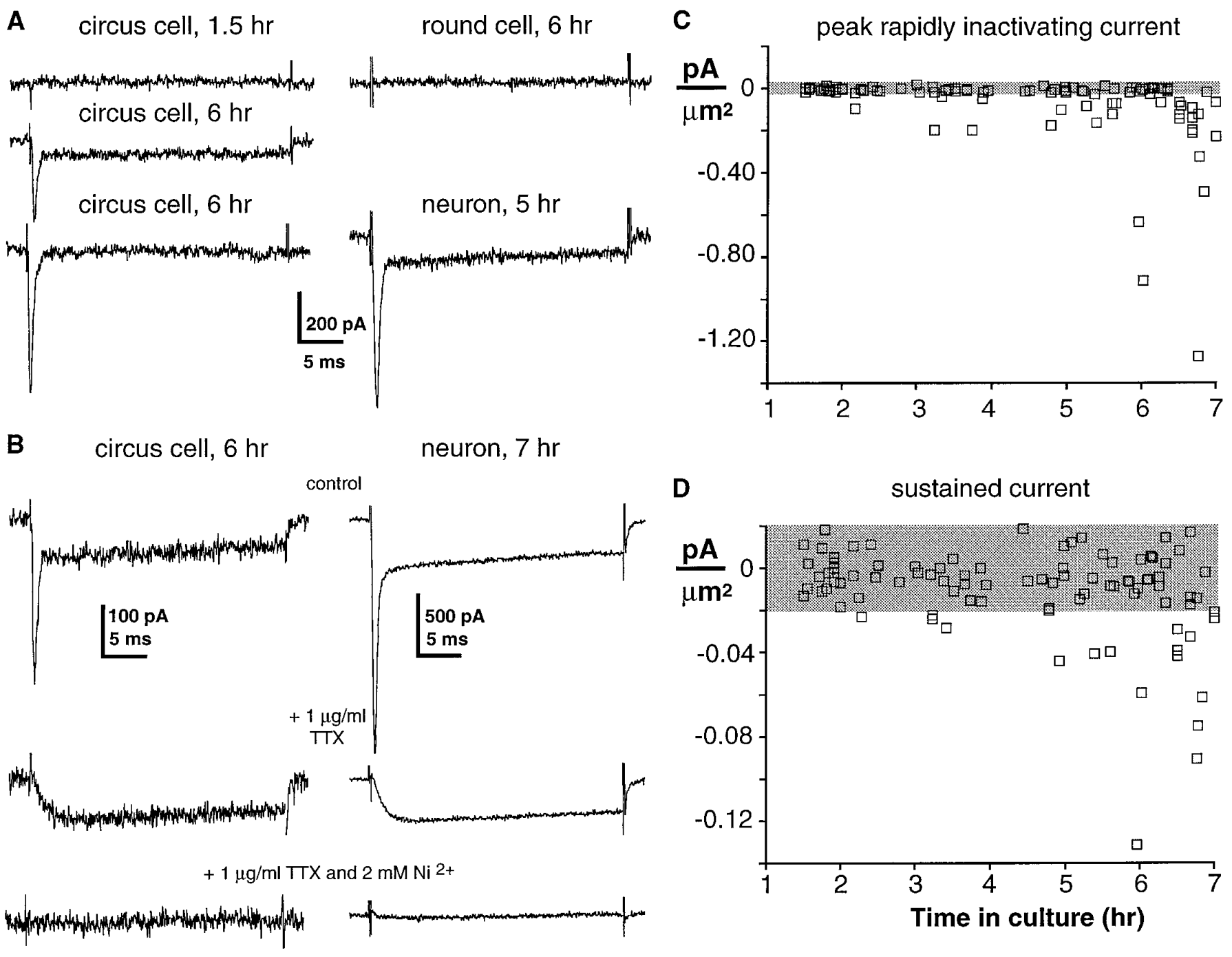

Figure 7. Appearance of voltage-dependent $\mathrm{Na}^{+}$and $\mathrm{Ca}^{2+}$ currents in circus cells from neurectoderm. Voltage-clamped currents were elicited during the first $6 \mathrm{hr}$ in culture by a $30 \mathrm{msec}$ voltage step from a holding potential of $-100 \mathrm{mV}$ to $0 \mathrm{mV}$. $A$, Inward currents are not detected in a circus cell at $1.5 \mathrm{hr}$ in culture (left top). Both rapidly inactivating and sustained components of inward current are present at $6 \mathrm{hr}$ (left middle) in some circus cells, whereas other circus cells demonstrate only the rapidly inactivating component (left bottom) or no inward currents at all (not shown). A round cell examined at $6 \mathrm{hr}$ does not demonstrate inward currents (right top), whereas a neuron examined at $6 \mathrm{hr}$ has both rapidly inactivating and sustained currents (right bottom). B, Pharmacological blockade of rapidly inactivating and sustained inward currents. The rapid component of the inward current is blocked by $1 \mu \mathrm{g} / \mathrm{ml}$ TTX, and the remaining sustained component is blocked by further addition of $2 \mathrm{mM} \mathrm{Ni}^{2+}$ in a circus cell (left) and in a neuron (right). Voltage-clamp protocol as in $A$. C, D, Aggregate measurements of $I_{\mathrm{Na}}$ and $I_{\mathrm{Ca}}$ during early development. Current densities $\left(\mathrm{pA} / \mu \mathrm{m}^{2}\right)$ of individual circus cells are plotted against time in culture. Mean peak-to-peak recording noise is denoted by the shaded horizontal bar.

morphological differentiation (Fig. 7B, right) (O'Dowd et al., 1988).

Elevations of $\left[\mathrm{Ca}^{2+}\right]_{\mathrm{i}}$ were elicited in $2 \%$ of circus cells at $2 \mathrm{hr}$ in culture; this figure rose to $13 \%$ by $3 \mathrm{hr}$ in culture and $43 \%$ by $6 \mathrm{hr}$ in culture (Fig. 9, white plus shaded bars). In addition to responsive circus cells that became morphologically differentiated neurons (shaded bars), a population of responsive circus cells that did not differentiate was identified (white bars), suggesting that some neurons develop voltage-dependent currents without differentiating morphologically. A small population of round cells responded to depolarization (Fig. 9, black bars), but the majority was unresponsive. The development of $I_{\mathrm{Ca}}$ measured by voltageclamp (Fig. $7 E$ ) is qualitatively similar to the development of responsive cells measured by $\mathrm{Ca}^{2+}$ imaging (Fig. 9). At $6 \mathrm{hr}, 38 \%$ of cells $(n=26)$ demonstrated $I_{\mathrm{Ca}}$, and $43 \%(n=40)$ of circus cells were responsive to $50 \mathrm{~mm} \mathrm{KCl}$. Disparities between results at other time points may be the result of contribution to the imaged signal from $\mathrm{Ca}^{2+}$ stores or to differences in staging. These findings suggest that the small $I_{\mathrm{Ca}}$ detected by voltage-clamp is capable of elevating $\left[\mathrm{Ca}^{2+}\right]_{\mathrm{i}}$ in response to depolarization in intact cells and that the development of $I_{\mathrm{Ca}}$ measured by these two techniques is similar.

\section{Calcium elevations elicited in single cells before morphological differentiation}

An interval of 1-3 hr between the appearance of $\mathrm{Ca}^{2+}$ currents and subsequent morphological differentiation is suggested by comparison of the development of $\mathrm{KCl}$ responses in circus cells with a neuronal fate (Fig. 9) and the time course of appearance of morphologically differentiated neurons in these cultures (Fig. $2 B$ ). This estimate, however, is based on population averages and assumes that earliest responding neurons are also the earliest to 

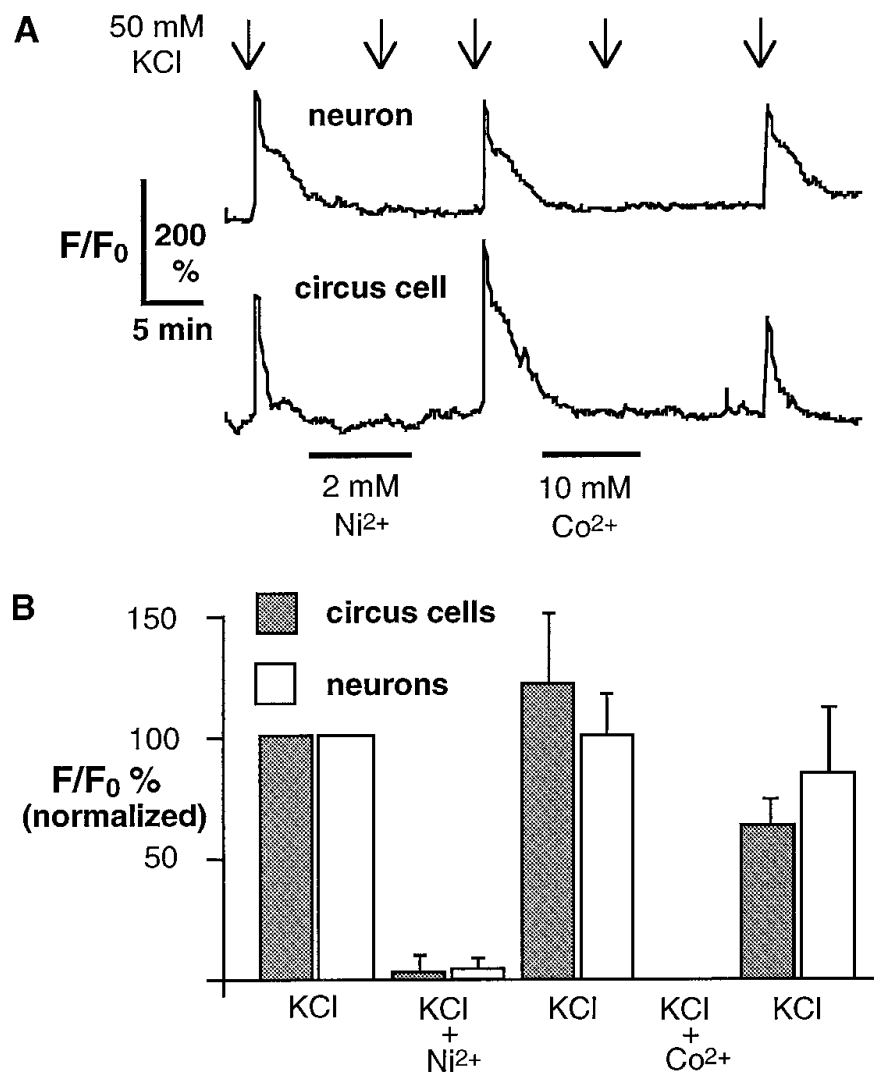

Figure 8. Voltage-dependent elevations of $\left[\mathrm{Ca}^{2+}\right]_{\mathrm{i}}$ in neurons and circus cells assessed by increases in Fluo-3 fluorescence. $A$, A neuron and a circus cell demonstrate elevations of $\mathrm{Ca}^{2+}$ in response to $30 \mathrm{sec}$ depolarization with $50 \mathrm{~mm} \mathrm{KCl}$ at $5 \mathrm{hr}$ in culture. Elevations are blocked by $2 \mathrm{mM} \mathrm{Ni}{ }^{2+}$ and $10 \mathrm{mM} \mathrm{Co}^{2+} . B$, Cumulative data normalized to first $\mathrm{KCl}$ response. Both $2 \mathrm{mM} \mathrm{Ni}^{2+}$ and $10 \mathrm{mM} \mathrm{Co}^{2+}$ completely block fluorescence increases resulting from $\mathrm{KCl}$ application, suggesting that they require activation of voltage-dependent $\mathrm{Ca}^{2+}$ channels. Means are from seven circus cells and four neurons from five cultures, 5-7 hr in culture.

differentiate morphologically. To confirm that all neurons have $\mathrm{Ca}^{2+}$ currents before morphological differentiation and to verify the estimated 1-3 $\mathrm{hr}$ period between the appearance of these currents and subsequent morphological differentiation, a singlecell analysis of the appearance of the $\mathrm{KCl}$ response was undertaken in which morphology was assessed simultaneously. Fluorescence and transmission images were acquired using the two photomultipliers of the confocal microscope. Fields containing Fluo-3AM-loaded circus cells were depolarized once per hour with $50 \mathrm{~mm} \mathrm{KCl}$, and fluorescent images were acquired at $5 \mathrm{sec}$ intervals during depolarizations but not between depolarizations. To assess morphology, transmission images were acquired during depolarizations and at $\sim 20$ min intervals between depolarizations. Morphological differentiation was defined as the time at which neurons stopped circus activity and spread on the dish; initiation of stable neurites typically occurred within $1 \mathrm{hr}$ after cell spreading. Individual fields of cells were followed for periods of up to 5 hr; data from responsive cells were excluded if the time of first response could not be determined because they demonstrated a response to the first depolarization, or if they failed to differentiate as assayed by spreading on the culture dish.

Most neurons demonstrated a response to $\mathrm{KCl}$ during their circus period $(85 \%, n=20)$, and all neurons exhibited elevations of $\left[\mathrm{Ca}^{2+}\right]_{\mathrm{i}}$ by the time they had spread on the substrate and

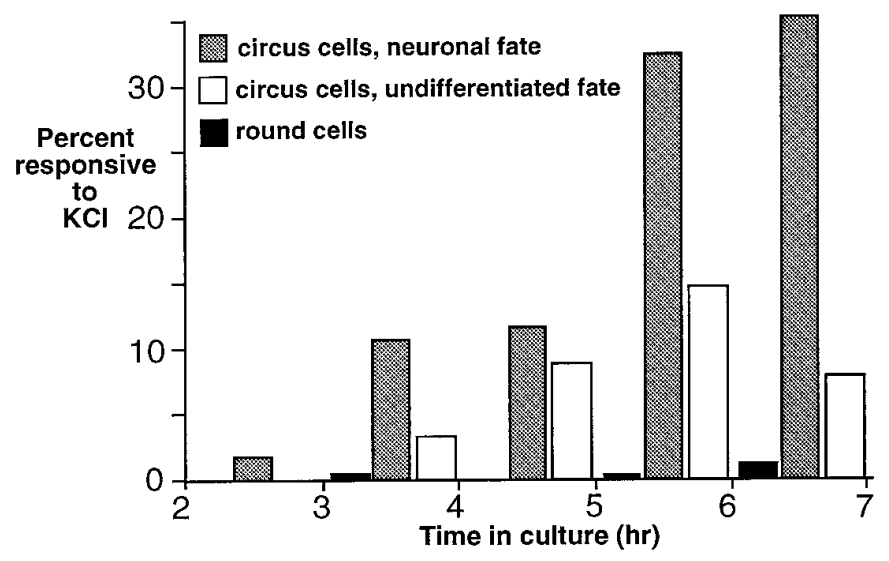

Figure 9. The percentage of neurectoderm circus cells demonstrating elevation of $\left[\mathrm{Ca}^{2+}\right]_{\mathrm{i}}$ in response to depolarization with $50 \mathrm{mM} \mathrm{KCl}$ increases with time in culture. Responses are detected in circus cells that subsequently differentiate into explicit neurons (shaded bars). An additional population of circus cells responds to $\mathrm{KCl}$ but later fails to differentiate morphologically (white bars), and a small population of round cells also responds to $\mathrm{KCl}$ challenge (black bars). An average of 30 cells from five cultures were sampled for each hour.

extended neurites. Individual cells demonstrated their first response up to $4 \mathrm{hr}$ before spreading and on average $\sim 2 \mathrm{hr}(110 \pm$ $20 \mathrm{~min}$ ) before morphological differentiation (Fig. 10). These results demonstrate that the majority of neurons acquires voltagedependent $\mathrm{Ca}^{2+}$ currents during their period of circus movements and confirm the interval of $1-3 \mathrm{hr}$ between first $\mathrm{KCl}$ response and morphological differentiation suggested by the population studies.

\section{DISCUSSION}

\section{Functional significance of circus movements}

Persistent circus movements precede differentiation of spinal neurons and myocytes cultured from Xenopus neural plate stage embryos. These movements, however, are not necessary for neuronal differentiation, because circus movement blockade by cytochalasin B does not prevent subsequent neurite initiation or depolarization-elicited elevation of $\left[\mathrm{Ca}^{2+}\right]_{\mathrm{i}}$. The significance of these movements may be understood best by considering their possible role in cellular migration. Preliminary studies of intact Xenopus neurula stage embryos reveal deep cells in the neural plate translocating by rapid bleb protrusions (unpublished observations). These cellular translocations appear similar to those described previously for the motile deep cells of Fundulus blastula and gastrula (Trinkaus, 1973), in which lobopodial extension and adhesion are followed by contraction and net cellular movement. Although various factors (e.g., contact inhibition of movement) could regulate the motility of circus cells in vivo, Xenopus primary spinal neurons may have a developmental profile similar to differentiating neurons in both cerebral cortex (Rakic, 1972; McConnell, 1991) and spinal cord (Chu-Wang et al., 1981; Leber and Sanes, 1995), wherein a period of postmitotic migration occurs before morphological differentiation. This comparison is supported further by the shared cytochalasin B-dependence of circus movements and neuronal migration (Rivas and Hatten, 1995). Because myogenic precursors are known to migrate into the developing chick limb bud (VanSwearingen and Lance-Jones, 1993), these observations collectively suggest that the persistent circus movements of primary neurons and myocytes correspond to migratory behaviors in the neural plate and paraxial mesoderm, respectively. 


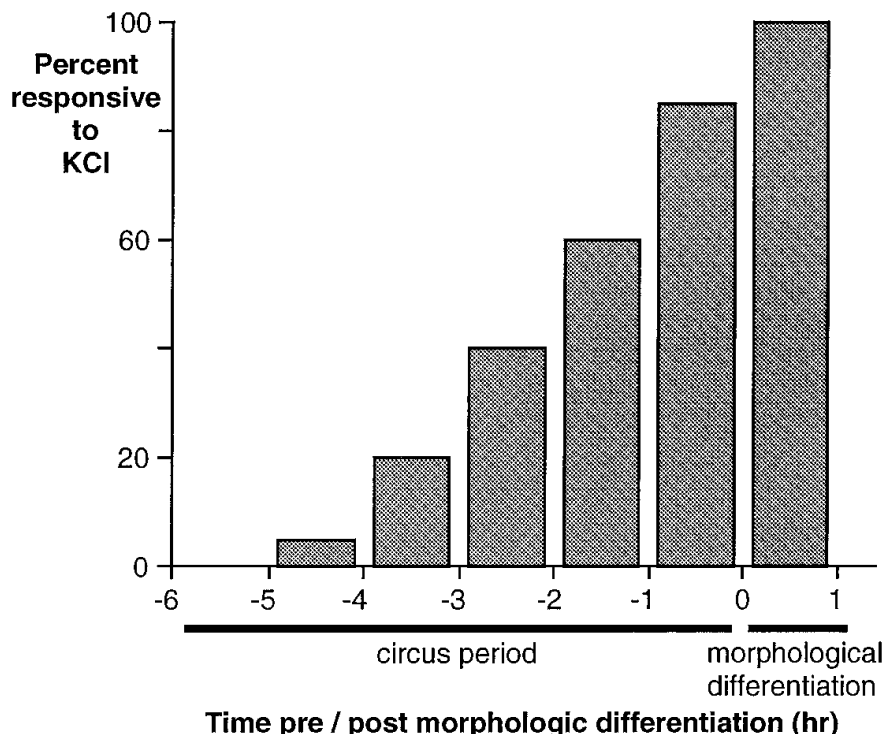

Figure 10. Voltage-dependent elevations of $\left[\mathrm{Ca}^{2+}\right]_{\mathrm{i}}$ are elicited in the majority of neurons during their circus period. Analysis of single cells reveals that the response to $\mathrm{KCl}$ precedes neurite initiation by $110 \pm 20$ min. Fluo-3AM-loaded circus neurectoderm cells were depolarized hourly with $50 \mathrm{~mm} \mathrm{KCl}$ and monitored for neurite initiation at $20 \mathrm{~min}$ intervals. Cumulative histogram of results from 21 cells.

Transient circus movements are observed during the first 30 min in cultures from the ectodermal and mesodermal layers of the neural plate and in reduced amounts in cultures from the endoderm and ventral ectoderm. This transient circus behavior may reflect the roles of these tissues in the morphogenesis of the lengthening neurula stage embryo, because the tissues that are actively extending in the gastrula (Keller and Danilchik, 1988) are richest in circus cells in the neurula. Several other lines of evidence link circus behavior to morphogenesis. Circus cells are first observed in dissociated cells from the midblastula stage embryo, but the percentage of circus cells rises dramatically at the onset of gastrulation (Fujinami and Kageyama, 1975; Johnson, 1976; Minoura et al., 1995). Moreover, tissues from hybrid frog embryos that fail to gastrulate exhibit reduced amounts of circus cells when dissociated and cultured (Johnson and Adelman, 1981, 1984). Lastly, mesoderm-inducing growth factors can induce circus movements in dissociated cells from the animal cap of the blastula (Minoura et al., 1995). The significance of circus behavior of the gastrulating embryo suggests that the transient circus behavior observed in the present study may be important for the morphogenetic rearrangements of the neurulating embryo.

\section{Marker for studies of development of excitability}

The fact that developing neurons exhibit circus movements in culture has allowed investigation of the initial expression of voltage-dependent currents. Because no inward or outward currents were recorded in circus cells at $1.5 \mathrm{hr}$ in culture and neurons are a subset of the circus cell population, it can be concluded that neurons do not have inward or outward currents at $1.5 \mathrm{hr}$ in culture (stage 17 in vivo). How valid is the attribution of the subsequent appearance of currents in circus cells to differentiating neurons? Could the development of currents in circus cells represent the onset of electrical excitability in both neurons and glia? It seems unlikely that electrically excitable glia (Barres et al., 1988) confound the developmental profile of the currents. Xeno- pus embryos are immunopositive for glial fibrillary acidic protein (GFAP) by stage 23 (Messenger and Warner, 1989), and fatemapping studies of neurula stage embryos demonstrate that clones containing primary neurons can also contain glia (Hartenstein, 1989). Glial $\mathrm{Na}^{+}$currents, however, typically have slower activation kinetics than neuronal $\mathrm{Na}^{+}$currents (Barres et al., 1989), and the currents measured in this study were uniformly rapid and kinetically similar to those in neurons; thus the likelihood of glial contamination is small. It is possible that most persistent circus cells are primary neurons but that many fail to differentiate in vitro. If electrical excitability at $16-24 \mathrm{hr}$ in culture is used as the criterion for neuronal differentiation rather than morphology, then $58 \%$ of persistent circus cells become neurons, making the identity of $42 \%$ of persistent circus cells uncertain. Because only $\sim 300$ of $>1000$ primary neurons (Hartenstein, 1993) in the Xenopus spinal cord differentiate morphologically and physiologically in vitro, the identity of the persistent circus population that fails to differentiate may also be neuronal. Examination of the persistent circus population for markers of primary neurons, such as Islet-1 (Ericson et al., 1992) and $\beta$ tubulin (Richter et al., 1988) as well as glial markers like GFAP, may resolve their identity.

\section{Order of appearance of currents}

In previous studies of Xenopus spinal neurons after morphological differentiation, voltage-dependent $\mathrm{Na}^{+}, \mathrm{Ca}^{2+}$, and $\mathrm{K}^{+}$currents were apparent. Whether or not morphologically undifferentiated neurons had voltage-dependent inward and outward currents was unknown, as was the order of appearance of these currents. In other systems in which neurons have been examined before the appearance of action potentials, voltage-dependent $\mathrm{K}^{+}$currents are recorded (Goodman and Spitzer, 1981; Bader et al., 1983) before detection of $\mathrm{Na}^{+}$or $\mathrm{Ca}^{2+}$ currents that can appear in either order (Gottmann et al., 1988; Krieger and Sears, 1988; Kubo, 1989; McCobb et al., 1989, 1990; Dietzel, 1995). The incidence of circus cells with detectable inward and outward currents increases with time in culture; at $1.5 \mathrm{hr}$ in culture, circus cells lacked voltage-dependent currents; by $6 \mathrm{hr}, 15 / 26$ of the circus cell population had $I_{\mathrm{Na}}, 9 / 26$ had $I_{\mathrm{Ca}}$, and 14/18 had $I_{\mathrm{Kv}} \cdot I_{\mathrm{Kv}}$ is already present when inward currents become detectable. Because six cells demonstrated $I_{\mathrm{Na}}$ without detectable $I_{\mathrm{Ca}}$ and no cells had $I_{\mathrm{Ca}}$ alone, $I_{\mathrm{Na}}$ may develop before $I_{\mathrm{Ca}}$. That $I_{\mathrm{Na}}$ can be detected in the absence of $I_{\mathrm{Ca}}$ does not necessarily imply differential functional expression of the channels underlying the two currents, because the fourfold difference in size of the currents at $6 \mathrm{hr}$ in culture predicts that even in the case of simultaneous upregulation of both currents, $I_{\mathrm{Na}}$ will be detected first. $I_{\mathrm{Na}}$ is detected before $I_{\mathrm{Ca}}$ in differentiating murine spinal neurons; however, if external calcium concentrations are raised 10- to 20-fold and $I_{\mathrm{Kv}}$ is blocked with TEACl, then $I_{\mathrm{Ca}}$ is detectable as early as $I_{\mathrm{Na}}$ (Krieger and Sears, 1988).

The densities of high voltage-activated calcium and potassium currents recorded from circus cells and young neurons grown on laminin/polylysine (this study) are smaller than those recorded from young neurons grown on tissue-culture plastic (O'Dowd et al., 1988). When corrections are made for the differences in recording conditions (e.g., for differences in driving force), however, the ratio of $I_{\mathrm{Ca}}$ to $\mathrm{I}_{\mathrm{Kv}}$ is very close to 1 in each case, indicating that circus cells and young neurons at $4-5 \mathrm{hr}$ in culture on laminin/polylysine are likely to generate long-duration calcium-dependent action potentials (Lockery and Spitzer, 1992). This conclusion is in agreement with recordings of long-duration 
calcium-dependent action potentials from young neurons in the spinal cord at a stage equivalent to $4-5 \mathrm{hr}$ in culture (Baccaglini and Spitzer, 1977). Differences in the amplitudes of currents may be attributable to differences in the age of cells at the time the recordings were made, during this period of developmental changes in current amplitude. Additionally, growth on laminin/ polylysine may affect the expression of the currents.

Although inward currents in circus cells at $6 \mathrm{hr}$ are approximately half the size of those in age-matched neurons, upregulation of currents is probably continuous. Two distinct populations of cells are being considered. Young neurons at $6 \mathrm{hr}$ in culture are the earliest to differentiate, whereas circus cells at $6 \mathrm{hr}$ include neurons that will differentiate morphologically throughout the next $\sim 14$ hr (Fig. 2B). Because the largest currents measured in circus cells are as large as or larger than those in age-matched neurons, it is unlikely that there is a sharp upregulation of currents at precisely the time of morphological differentiation.

\section{Spontaneous elevations of $\left[\mathrm{Ca}^{2+}\right]_{i}$ in relation to the appearance of $I_{\mathrm{Ca}}$}

Previous studies demonstrated that differentiating Xenopus spinal neurons spontaneously elevate $\left[\mathrm{Ca}^{2+}\right]_{i}$ before and after neurite initiation. Brief $\mathrm{Ca}^{2+}$ transients, termed spikes, are triggered by action potentials and are necessary for normal neurotransmitter expression (Holliday and Spitzer, 1990; Gu et al., 1994; Gu and Spitzer, 1995) and $\mathrm{K}^{+}$current maturation (Desarmenien and Spitzer, 1991; Gu and Spitzer, 1995). Spikes appear at low frequency in morphologically undifferentiated neurons at 3-4 hr in culture (Gu and Spitzer, 1995), when depolarization elicits elevations of $\left[\mathrm{Ca}^{2+}\right]_{\mathrm{i}}$ in $\sim 10 \%$ of circus cells. The parallel appearance of spontaneous elevations in the previous study and depolarization-elicited elevations of $\left[\mathrm{Ca}^{2+}\right]_{\mathrm{i}}$ in this study suggest the functional relevance of these early expressed currents; this suggestion is also supported by observations that $\mathrm{Ni}^{2+}$ and $\mathrm{Co}^{2+}$ block these channels and prevent spikes (Gu et al., 1994). Because a majority of morphologically undifferentiated cells examined in the earlier study were spread cells that lacked neurites rather than circus cells, further study will be required to determine whether action potentials can and do trigger spikes in neurons during their circus period. Nonetheless, the correlation between the time of onset of spontaneous activity and the appearance of depolarization-induced elevation of $\left[\mathrm{Ca}^{2+}\right]_{\mathrm{i}}$ at 3-4 $\mathrm{hr}$ in culture, at least $1 \mathrm{hr}$ before the onset of morphological differentiation, points to a functional role for these voltage-dependent currents. Finally, these results suggest that a mechanism capable of depolarizing neurons to levels sufficient to activate voltage-dependent $\mathrm{Ca}^{2+}$ channels may also be present before or concurrent with appearance of $\mathrm{Ca}^{2+}$ channels. This study indicates that the development of voltage-dependent $\mathrm{Ca}^{2+}$ channels is paralleled by the development of spontaneous activity in these cultures and defines the start of the period during which electrical excitability can shape the differentiation of primary spinal neurons.

\section{REFERENCES}

Baccaglini PI, Spitzer NC (1977) Developmental changes in the inward current of the action potential of Rohon-Beard neurones. J Physiol (Lond) 271:93-117.

Bader CR, Bertrand D, Kato AC (1983) Membrane currents in a developing parasympathetic ganglion. Dev Biol 98:515-519.

Barish ME (1986) Differentiation of voltage-gated potassium current and modulation of excitability in cultured amphibian spinal neurones. J Physiol (Lond) 375:229-250.

Barres BA, Chun LL, Corey DP (1988) Ion channel expression by white matter glia. I. Type 2 astrocytes and oligodendrocytes. Glia 1:10-30.
Barres BA, Chun LL, Corey DP (1989) Glial and neuronal forms of the voltage-dependent sodium channel: characteristics and cell-type distribution. Neuron 2:1375-1388.

Chu-Wang IW, Oppenheim RW, Farel PB (1981) Ultrastructure of migrating spinal motoneurons in anuran larvae. Brain Res 213:307-318.

Desarmenien MG, Spitzer NC (1991) Role of calcium and protein kinase $\mathrm{C}$ in development of the delayed rectifier potassium current in Xenopus spinal neurons. Neuron 7:797-805.

Desarmenien MG, Clendening B, Spitzer NC (1993) In vivo development of voltage-dependent ionic currents in embryonic Xenopus spinal neurons. J Neurosci 13:2575-2581.

Dietzel ID (1995) Voltage-gated ion currents in embryogenesis. Perspect Dev Neurobiol 2:293-308.

Ericson J, Thor S, Edlund T, Jessell TM, Yamada T (1992) Early stages of motor neuron differentiation revealed by expression of homeobox gene Islet-1. Science 256:1555-1560.

Ernsberger U, Spitzer NC (1995) Convertible modes of inactivation of potassium channels in Xenopus myocytes differentiating in vitro. J Physiol (Lond) 484:313-329.

Fujinami N (1976) Studies on the mechanism of circus movement in dissociated embryonic cells of a teleost, Oryzias latipes: fine-structural observations. J Cell Sci 22:133-147.

Fujinami N, Kageyama T (1975) Circus movement in dissociated embryonic cells of a teleost, Oryzias latipes. J Cell Sci 19:169-182.

Goodman CS, Spitzer NC (1981) The development of electrical properties of identified neurones in grasshopper embryos. J Physiol (Lond) 313:385-403.

Gottmann K, Dietzel ID, Lux HD, Huck S, Rohrer H (1988) Development of inward currents in chick sensory and autonomic neuronal precursor cells in culture. J Neurosci 8:3722-3732.

Grant P, Tseng Y (1989) In vitro growth properties of Xenopus retinal neurons undergo developmental modulation. Dev Biol 133:502-514.

$\mathrm{Gu}$ X, Spitzer NC (1993) Low-threshold $\mathrm{Ca}^{2+}$ current and its role in spontaneous elevations of intracellular $\mathrm{Ca}^{2+}$ in developing Xenopus neurons. J Neurosci 13:4936-4948.

Gu X, Spitzer NC (1995) Distinct aspects of neuronal differentiation encoded by frequency of spontaneous $\mathrm{Ca}^{2+}$ transients. Nature 375:784-787.

Gu X, Olson EC, Spitzer NC (1994) Spontaneous neuronal calcium spikes and waves during early differentiation. J Neurosci 14:6325-6335.

Hamill OP, Marty A, Neher E, Sakmann B, Sigworth FJ (1981) Improved patch-clamp techniques for high-resolution current recording from cells and cell-free membrane patches. Pflügers Arch 391:85-100.

Hartenstein V (1989) Early neurogenesis in Xenopus: the spatiotemporal pattern of proliferation and cell lineages in the embryonic spinal cord. Neuron 3:399-411.

Hartenstein V (1993) Early pattern of neuronal differentiation in the Xenopus embryonic brainstem and spinal cord. J Comp Neurol 328:213-231.

Holliday J, Spitzer NC (1990) Spontaneous calcium influx and its roles in differentiation of spinal neurons in culture. Dev Biol 141:13-23.

Holliday J, Adams RJ, Sejnowski TJ, Spitzer NC (1991) Calcium-induced release of calcium regulates differentiation of cultured spinal neurons. Neuron 7:787-796.

Holtfreter J (1946a) Structure, motility and locomotion in isolated embryonic amphibian cells. J Morphol 79:27-62.

Holtfreter J (1946b) Observations on the migration, aggregation and phagocytosis of embryonic cells. J Morphol 80:25-55.

Hussy N (1991) Developmental change in calcium-activated chloride current during the differentiation of Xenopus spinal neurons in culture. Dev Biol 147:225-238.

Johnson KE (1976) Circus movements and blebbing locomotion in dissociated embryonic cells of an amphibian, Xenopus laevis. J Cell Sci 22:575-583.

Johnson KE, Adelman MR (1981) Circus movements in dissociated cells in normal and hybrid frog embryos. J Cell Sci 49:205-216.

Johnson KE, Adelman MR (1984) Circus movements in dissociated cells from two new hybrid frog embryos. J Cell Sci 68:69-82.

Karasaki S (1957) On the mechanism of the dorsalization in the ectoderm of Triturus gastrulae caused by precytolytic treatments. I. Cytological and morphogenetic effects of various injurious agents. Embryologica 3:317-334.

Keller R (1975) Vital dye mapping of the gastrula and neurula of Xenopus laevis. I. Prospective areas and morphogenetic movements of the superficial layer. Dev Biol 42:222-241. 
Keller R (1976) Vital dye mapping of the gastrula and neurula of Xenopus laevis. II. Prospective areas and morphogenetic movements of the deep layer. Dev Biol 51:118-137.

Keller R, Danilchik M (1988) Regional expression, pattern and timing of convergence and extension during gastrulation of Xenopus laevis. Development 203:193-209.

Keller R, Shih J, Sater A (1992) The cellular basis of convergence and extension of the Xenopus neural plate. Dev Dynamics 193:193-217.

Kidokoro Y, Sand O (1989) Action potentials and sodium inward currents of developing neurons in Xenopus nerve-muscle cultures. Neurosci Res 6:191-208.

Kidokoro Y, Anderson MJ, Gruener R (1980) Changes in synaptic potential properties during acetylcholine receptor accumulation and neurospecific interactions in Xenopus nerve-muscle cell culture. Dev Biol 78:464-483.

Komuro H, Rakic P (1992) Selective role of N-type calcium channels in neuronal migration. Science 257:806-809.

Komuro H, Rakic P (1993) Modulation of neuronal migration by NMDA receptors. Science 260:95-97.

Komuro H, Rakic P (1995) Dynamics of granule cell migration: a confocal microscopic study in acute cerebellar slice preparations. J Neurosci 15:1110-1120.

Krieger C, Sears TA (1988) The development of voltage-dependent ionic conductances in murine spinal cord neurones in culture. Can J Physiol Pharmacol 66:1328-1336.

Kubo Y (1989) Development of ion channels and neurofilaments during neuronal differentiation of mouse embryonal carcinoma cell lines. J Physiol (Lond) 409:497-523.

Leber SM, Sanes JR (1995) Migratory paths of neurons and glia in the embryonic chick spinal cord. J Neurosci 15:1236-1248.

Linsdell P, Moody WJ (1994) $\mathrm{Na}^{+}$channel mis-expression accelerates $\mathrm{K}^{+}$channel development in embryonic Xenopus laevis skeletal muscle. J Physiol (Lond) 480:405-410.

Linsdell P, Moody WJ (1995) Electrical activity and calcium influx regulate ion channel development in embryonic Xenopus skeletal muscle. J Neurosci 15:4507-4514.

Lockery SR, Spitzer NC (1992) Reconstruction of action potential development from whole-cell currents of differentiating spinal neurons. J Neurosci 12:2268-2287.

Loeb L (1928) Amoebocyte tissue and and amoeboid movements. Protoplasma 4:596-625.

McCobb DP, Best PM, Beam KG (1989) Development alters the expression of calcium currents in chick limb motoneurons. Neuron 2:1633-1643.

McCobb DP, Best PM, Beam KG (1990) The differentiation of excitability in embryonic chick limb motoneurons. J Neurosci 10:2974-2984.

McConnell SK (1991) The generation of neuronal diversity in the central nervous system. Annu Rev Neurosci 14:269-300.

Messenger NJ, Warner AE (1989) The appearance of neural and glial cell markers during early development of the nervous system in the amphibian embryo. Development 107:43-54.
Minoura I, Nakamura H, Tashiro K, Shiokawa K (1995) Stimulation of circus movement by activin, bFGF and TGF-beta 2 in isolated animal cap cells of Xenopus laevis. Mech Dev 49:65-69.

Minta A, Kao JP, Tsien RY (1989) Fluorescent indicators for cytosolic calcium based on rhodamine and fluorescein chromophores. J Biol Chem 264:8171-8178.

Nieuwkoop JM, Faber J (1967) Normal table of Xenopus laevis (Daudin): a systematic and chronological survey of the development of the fertilized egg till the end of metamorphosis. Amsterdam: North Holland.

O'Dowd DK, Ribera AB, Spitzer NC (1988) Development of voltagedependent calcium, sodium, and potassium currents in Xenopus spinal neurons. J Neurosci 8:792-805.

Olson EC (1994) Ruffling plasma membrane predict differentiation of embryonic neurons. Soc Neurosci Abstr 20:242.

Olson EC, Gu X (1993) Voltage-gated $\mathrm{Ca}^{2+}$ channels and DTBHQsensitivity are upregulated prior to the onset of spontaneous $\mathrm{Ca}^{2+}$ spiking and neurite outgrowth. Soc Neurosci Abstr 19:1111.

Rakic P (1972) Mode of cell migration to the superficial layers of fetal monkey neocortex. J Comp Neurol 145:61-83.

Rhumbler L (1898) Physikalische analyse von lebensercheinungen der zelle. I. Bewegung nahrungsaufnahme defäkation vacuolen-pulsation und gehäusebau bei lobosen rhizopoden. Arch Entwicklungsmech Org 7:103-350.

Ribera AB, Spitzer NC (1987) Both barium and calcium activate neuronal potassium currents. Proc Natl Acad Sci USA 84:6577-6581.

Richter K, Grunz H, Dawid IB (1988) Gene expression in the embryonic nervous system of Xenopus laevis. Proc Natl Acad Sci USA 85:8086-8090.

Rivas RJ, Hatten ME (1995) Motility and cytoskeletal organization of migrating cerebellar granule neurons. J Neurosci 15:981-989.

Roux W (1894) Über den 'Cytotropismus' der Furschungszellen des Grasfrosches (Rana fusca). Arch Entwicklungsmech Org 1:43-68.

Sirakami KI (1963) Cyto-embryological studies of amphibians. IV. Behaviors of isolated ectodermal cells from blastula stage embryos of Bufo vulgaris. Mem Fac Lib Arts Educ Yamanashi Univ 10:132-140.

Spitzer NC (1991) A developmental handshake: neuronal control of ionic currents and their control of neuronal differentiation. J Neurobiol 22:659-673.

Spitzer NC, Lamborghini JE (1976) The development of the action potential mechanism of amphibian neurons isolated in culture. Proc Natl Acad Sci USA 73:1641-1645.

Spitzer NC, Debaca RC, Allen KA, Holliday J (1993) Calcium dependence of differentiation of GABA immunoreactivity in spinal neurons. J Comp Neurol 337:168-175.

Trinkaus JP (1973) Surface activity and locomotion of Fundulus deep cells during blastula and gastrula stages. Dev Biol 30:69-103.

VanSwearingen JM, Lance-Jones C (1993) Spatial and temporal patterns of muscle formation in the limb of the avian embryo. Prog Clin Biol Res 383B:553-562. 